\title{
From Shipbreaking literature to sustainability framework for developing country recycling: a review
}

Sm Rahman

\begin{abstract}
:
Shipbreaking research has not been in the forefront until the last decade in which environmental and occupational hazards have been highlighted while economic sustainability and contextual conditions were not equally considered. The adoption of a triple bottom line approach across core business issues (environmental impacts, workplace safety ) as well as peripheral stakeholders expectation (environmental sustainability focus) has been retarded due to the less attention on the latter. Based on the findings of the 128 review papers, the study suggests that organizational learning and economic sustainability needs to prioritize through the formation of strange alliance among the stakeholders. The study argues that the dialogue and discussion on the peripheral stakeholders (NGOs, yard managers, national and international policy organizations) would lead to a more sustainable shipbreaking industry in the south Asian regions.
\end{abstract}

Keywords: shipbreaking, triple bottom line sustainability, strange alliance, organizational learning

\subsection{Introduction:}

The international shipbreaking industry provides a recycling service for commercial ships worldwide. More than $90 \%$ of end-of-life (EOL) ships are dismantled in five nations, representing a geographical shift from developed countries due to higher environmental and safety costs that render these activities uncompetitive there (Figure 1). South Asian recycling nations - Bangladesh, India, and Pakistan - share common cultural and economic challenges while China and Turkey enjoy relatively higher economic capacity and cultural conformity regarding sustainability. The shipbreaking industry benefits the host nations in terms of economic development, employment generation, and supply of critical metal resources. At the global level, the recycled metal scrap of EOL ships avoids environmental impacts of primary metal production and steel manufacturing (Rahman et al. 2016). 


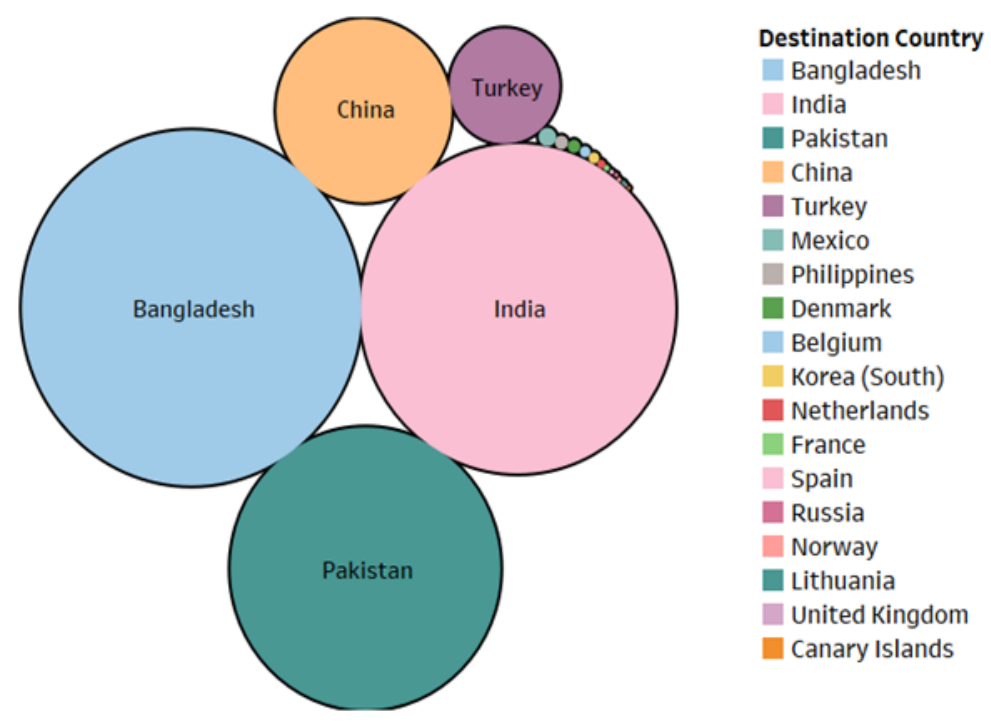

Figure 1: Global shipbreaking in gross tonnage (GT) in 2016: data from NGO Shipbreaking Platform, 2017

At the local level, shipbreaking industry faces internal and external challenges encompassing social, environmental and economic performances that involve multiple stakeholders with various cultural and business understandings and expectations (Cairns 2007, Neser et al. 2008, Hillier 2009, Demaria 2010, Gregson et al. 2012, Cairns 2014, Devault et al. 2017, Jain et al. 2016, Rahman and Mayer 2016). Stakeholders who influence or are directly impacted by the sustainability aspects of the current state of affairs include yard owners, NGOs (both national and international), ship-owners and brokers, international organizations (IOs), national governmental agencies, local and global academics, local communities, and the workers. Broadly speaking, ship-owners and yard-owners have an interest in securing economic bottom line (Jain et al. 2016, Schøyen et al. 2017), while NGOs and researchers mainly focus on social and environmental bottom lines (Andersen 2001, Neser et al. 2008, Hossain and Islam 2006, Reddy et al. 2003). International and national policymakers tend to formulate policies that mediate between economic bottom line, and environmental and social bottom lines - serving to the attainment of weak sustainability governance (Mikelis 2008, Cairns 2014, Rahman and Mayer 2016).

The current approach, as I argue, mostly focused on the immediate environmental and social impacts of the dismantling process, a boundary that I call 'core business boundary (CBB), while inadequately acknowledging the relevance of peripheral actors (NGOs, supply chains actors, IOs etc.). However, a comprehensive approach is missing that can reorganize 
the approaches and strategies of the actors in all levels. I, therefore, try to identify the gap in existing research pattern and suggest a conceptual framework that may promote sustainability of the industry. In this review, I assume that shipbreaking industry represents a business organization having stakeholders across the globe performing under different cultural aspirations and realities. I apply TBL sustainability framework to understand shipbreaking issues, challenges, and complexities.

\subsection{TBL framework:}

TBL framework evaluates environmental, economic and social performances of an organization, which includes profitability of the stakeholders and the considerations of social, human and environmental contexts under which the organization operates (Elkington 1998). TBL emphasises the certainty of economic bottom-line and tends to gradually adhere to social and environmental bottom lines that in turn strengthen economic bottom line, leading to a 'virtuous cycle' towards the attainment of TBL sustainability. From trans-boundary governance perspective, CBB centric TBL approach may entail the integration of another boundary -Peripheral Boundary (PB) - to deal with innovative issues and challenges, beyond CBB that interconnects geography, administration, supply chains and cultures across scales (Bostrom et al. 2015). Total Business Boundary (TBB) is defined here as a decision-making space that builds on collaboration and cooperation of both $\mathrm{CBB}$ and $\mathrm{PB}$ to deliver and merge varying actors' ideals, aspirations, and realities. CBB is defined as the boundary in which traditional business actors experience their operational contexts and social responsibilities whereas PB is defined as a boundary that exists beyond CBB consisting of actors, processes, and pressures that intricately influence CBB activities and strategies. In that sense, PB is perceived not as a boundary-spanning approach but instead acknowledged as an emerging reality rooted in western ideals that tend to shape secondary resources recovery business in the developing countries (Bostrom et al. 2015).

Total Business Boundary $(\mathrm{TBB})=$ Peripheral Boundary $(\mathrm{PB})+$ Core Business Boundary (CBB)

$\mathrm{PB}$ relates to $\mathrm{CBB}$ 's expectations and strategies in several ways. For example, Carter and Rogers (2008) demonstrate that risk management, transparency, strategy, and culture are supporting facets to attain desired TBL performance. They point out that supply chain risk reduces the ability for CBB to adhere to stakeholder's demands and ideals. Jamali and Nevile 
(2011) argue that convergence-divergence pressures (stakeholder beyond and within geographic reality) constantly struggle to dominate and determine the desired outcomes/impacts of the CBB, in which convergence tends to highlight (seek remedy of) environmental and social odds where divergence largely remains locked to cultural practices, resource supply constraints, and poor organizational performances. Lack of any effort to mediate such convergence-divergence duality may emerge as an obstacle for advancement and PB approach is likely to address this lacking. The new approach, that this paper takes, thus offers a platform to mediate the varying ideals through strange alliance formation, supply chain responsibility, and organizational learning; which are described below (Jamali 2006).

\subsubsection{Strange Alliance:}

An uneasy relationship exists between economic bottom line advocates and social and environmental bottom lines advocates (Jamali and Keshishian 2009). Economic bottom line and social and environmental bottom lines are thought to be antagonistic to the business owners from profit-making perspective, as social and environmental bottom lines signify apportioning economic resources, potentially cutting profit margin of the stakeholders. The core elements that increase distances among company and campaigners are the assumption of the alienated relationship between financial stability and social responsibility. In this context, NGOs-business manager relationships are often strange or uneasy (Jamali and Keshishian 2009). Most importantly, the uneasy relationship continues due to (1) lack of communication among the interest groups working on same areas and (2) absence of any platform to exchange strategies and visions that can identify shared values, shared goals and cooperative work plans (Jamali 2006). Alliance literature sketched a strategic approach and delineated mutually reinforcing conditions that may foster collaboration among the 'strange' probusiness and non-profit stakeholders toward more integrative partnerships (Jamali and Keshishian 2009). Different foundational components of the strange alliance are resource dependency, commitment symmetry, common goal symmetry, repetitive sequence of negotiation (Austin 2010). Elkington (1998) showed that common interest exists among businesses and NGOs in order to form alliance.

\subsubsection{Supply chain responsibility challenges:}

Supply chain issues are increasingly complex in six dimensions: geographic, informational, communication, compliance, power and legitimacy (Bostrom et al. 2015). Transformation in supply chains is effective when a focal business holds power over the suppliers and can exert at least two conditions: (1) maintain minimum standards in environmental and social bottom 
line (2) maintain consumer needs and economic competitiveness (Seuring and Muring 2008). Lack of such power over supply chains is prevalent in recycling businesses and often disconnected from dominant sustainability discourses, driven by actors at various levels. (Bostrom et al. 2015). This means that traditional CBB approach for TBL sustainability ought to be complemented by PB in that supply chain behaviours, performances and strategies are discussed and put to context against the core business contexts. Industrial transformation literature advocates a production system that suggests to co-ordinate horizontal and vertical supply chains skilfully and prescribes adaptive company management through the establishment of long-term embedded transactions among the stakeholders.

\subsubsection{TBL reporting and organizational learning opportunity:}

TBL reporting provides information to what extent an organization is contributing to and distracted from TBL sustainability (Hall 2011). The triple bottom line reporting through independent and rigorous auditing is likely to move business towards the socially responsible action. Over the years, businesses become capable to spontaneously initiate and perform actions that mutually benefit economic and social bottom lines. There exists three zones of business activities: (1) zone of discretion (2) zone of no conflict, and (3) zone of mutual benefits (Elkington 1998). "Zone of mutual benefits" are those areas of activities that mutually foster social as well as economic bottom lines together. Reporting helps identify more actions that fall under "zone of mutual benefit". For example, most of the big companies accorded in Forbes 100 top ranked entrepreneurs successfully identified (continue to identify) zones that satisfy both economic and social bottom lines (Hall 2011). It is unlikely that businesses act in a socially responsible way when the action is in the zone of discretion, meaning that a social action is in conflict with economic dictates (Robins 2006). In that case, socially responsible law and policy is required to boost businesses for strengthening social and environmental bottom lines. Therefore, the more actions that lie in Zone of mutual benefits are identified and pursued, the more a business is capable of attaining TBL sustainability. Disclosing information through reporting opens up such possibility.

\subsection{Research Methodology:}

I adopt Seuring and Muller's (2008) two objectives for reviewing the shipbreaking literature: 1) summarize the major patterns, themes and issues; and 2) identify research gaps and propose 
a conceptual framework for future research focus. They also describe a four-step review procedure: (1) study scope and literature search, 2) category selection, 3) descriptive analysis and 4) material evaluation.

\subsection{Literature search process:}

To determine the source material for review, I have followed three-step process, suggested by Webster and Watson (2002). Firstly, this paper utilized Scopus (as well as Google Scholar for specific search on Pakistan and Science Direct databases for verification purpose) to identify and verify relevant material. Secondly, I have applied backward search reviewing the citations of the already listed materials and finally, forward search for articles that are cited in listed materials.

Scopus is the largest abstract and citation database of peer-reviewed literature, with over 60 million records going back as far as 1823 . The database has enabling tools to track, analyse and visualize research. The keywords used are "Ship Breaking”, "Ship Recycling”, "Ship Scrapping”, “Ship Dismantling” and finally "Ship Demolition” in Title, abstract or keywords, with initial search results 109,87,32,38 and 7 respectively (Table 1). The results were saved in .csv file directly from Scopus website. Selection process was followed in several steps. Firstly, the results were checked for repeated articles. In this stage, 53 articles were found repeated or appeared without author name ( 9 of them). In next round, a quick title reading (whether title contains any of the keywords) were used. In this stage, 66 articles were excluded. Abstract of the articles, journal information, article type were, then, carefully read and full-text availability were searched, which further exclude additional 29 articles. Of them, 19 were conference papers and 10 were found completely irrelevant or marginally used the terms (Zott et al. 2011). Our main concern with the Scopus result was that this search did not return any studies on Pakistan shipbreaking, which is the third major shipbreaking nations after Bangladesh and India.

At this point, I searched Google Scholar with keywords "shipbreaking in Pakistan" that returned six papers, mainly unindexed articles, conferences papers and reports. I then conducted forward and backward search that added 18 more articles, some of them, did not use the above 'keywords' in the title but contents are relevant to shipbreaking (Zott et al. 2011). This totaled 128 articles for our review. To validate and ensure the exhaustive capture of the shipbreaking literature, I also ran a literature search in Science Direct using the same key words. Searching with "Ship Breaking” and "Ship Recycling” keywords returned 356 and 
97 articles respectively. Checking the articles that appeared in the latest three years from 2016 was found no additional article beyond our already included list, demonstrating the near inclusiveness of the search (Oxman 1993).

Table 1: Literature search process and returns

\begin{tabular}{|c|c|c|c|c|c|c|c|c|c|}
\hline Scopus keyword & $\begin{array}{c}\text { First } \\
\text { appearance }\end{array}$ & $\begin{array}{c}\text { Repeated } \\
\text { appearance } \\
\text { (Discard } \\
\text { of no } \\
\text { author) }\end{array}$ & $\begin{array}{c}\text { Title } \\
\text { reading }\end{array}$ & $\begin{array}{c}\text { Abstract } \\
\text { reading, } \\
\text { journal } \\
\text { sources } \\
\text { and } \\
\text { content }\end{array}$ & $\begin{array}{c}\text { Marginal } \\
\text { or trivial } \\
\text { use of } \\
\text { keywords }\end{array}$ & $\begin{array}{c}\text { Full } \\
\text { text } \\
\text { access }\end{array}$ & $\begin{array}{l}\text { Full } \\
\text { text } \\
\text { not } \\
\text { found }\end{array}$ & $\begin{array}{c}\text { Forward and } \\
\text { backward } \\
\text { search }\end{array}$ & Total \\
\hline Ship Breaking & 109 & 93 & 65 & 59 & 2 & 50 & 7 & 24 (6 Pakistan) & \\
\hline Ship Recycling & 87 & 74 & 57 & 43 & 1 & 37 & 5 & - & \\
\hline Ship Scrapping & 32 & 24 & 14 & 12 & $\mathbf{0}$ & 10 & 2 & - & \\
\hline Ship Dismantling & 38 & 25 & 14 & 7 & $\mathbf{1}$ & 5 & 1 & - & \\
\hline Ship Demolition & 7 & 4 & 4 & 4 & $\mathbf{0}$ & 2 & 2 & - & \\
\hline Total & 273 & 220 & 154 & 125 & 4 & 104 & 17 & 24 & 128 \\
\hline Discard & & 53 & 66 & 29 & & - & - & - & - \\
\hline
\end{tabular}

\subsection{Structural category and analytical approach:}

One of the criticisms of literature review is the author subjective conceptual structure (Webster and Watson 2002). In order to eliminate the issue, I have followed Fereday and Muir-Cochrane (2006) approach for the hybridization of literature-driven structures with theory-driven ones (Figure 2). I have used computerized coding system using Nvivo software following content analysis. Six questions have been used in conducting the content analysis (Krippendorff, 2018).

1. Which data are analyzed?

2. How are the data defined?

3. From what population are data drawn?

4. What is the relevant context?

5. What are the boundaries of the analysis?

6 . What is to be measured? 
The context of the given word identified in the software used for the content analysis can be found by going back to the paragraph/s of the related article. The population of the identified words is found through the number of publications the word is appeared. The boundaries and the unit of analysis is chosen based on the theme developed through the coding of the initial word references.

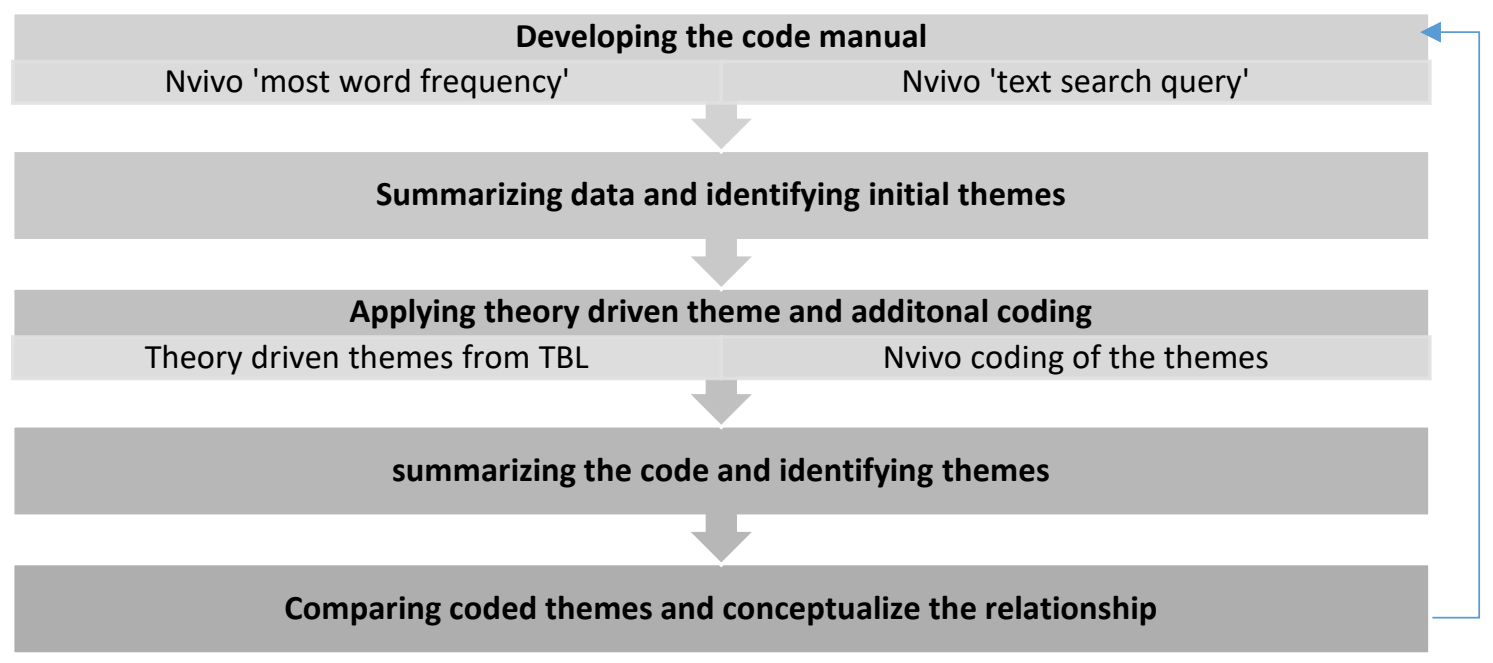

Figure 2: Coding and theme development process adapted from Fereday and Muir-Cochrane (2006)

\subsection{Results:}

\subsection{Papers by time, discipline and country}

Descriptive analysis was performed based on the distribution of scientific articles across time, discipline, and country. Figure 3 shows the rapidly increasing number of papers published since 2003. The figure also shows the absence of shipbreaking research from 1990 to 2000. 


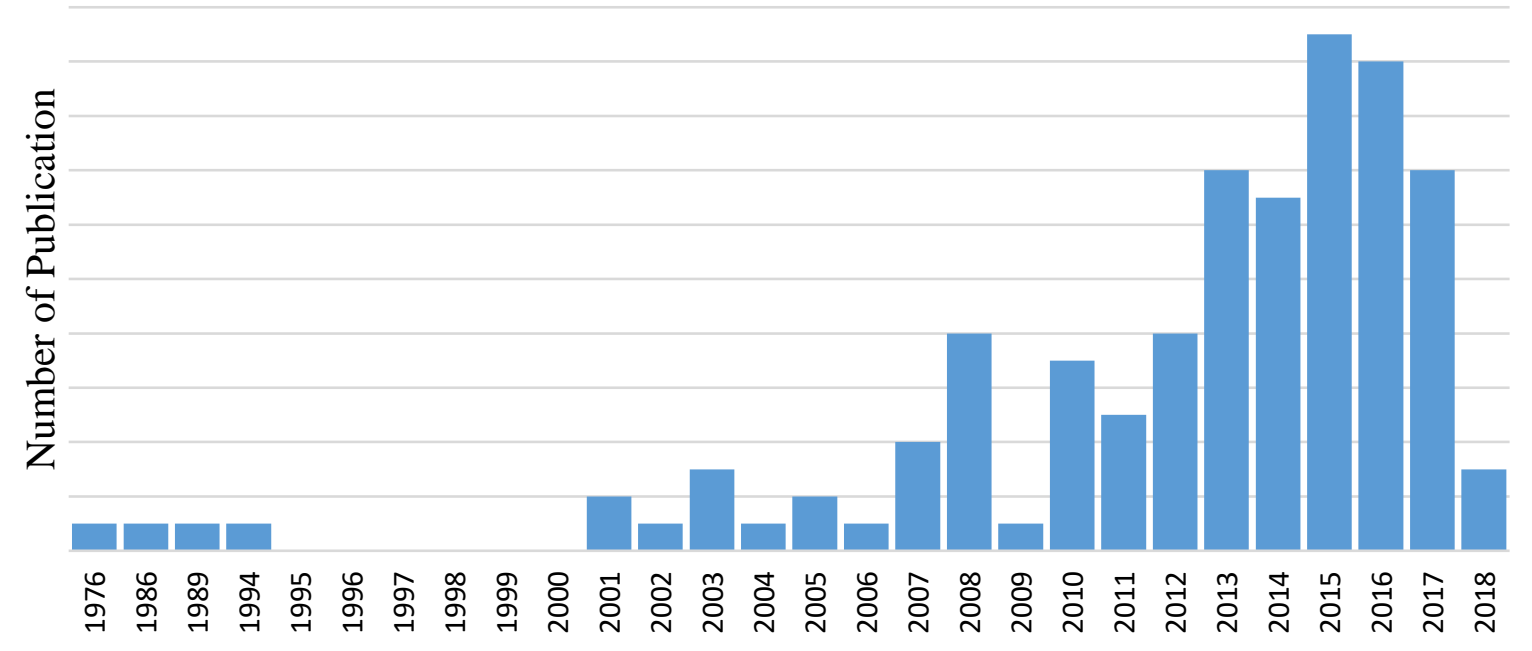

Figure 3: Shipbreaking literature published by year until April 2018.

The absence between 1990 and 2000 is probably due to the geographic shift of the shipbreaking industry from developed to developing countries. The focus of the earlier publications on the consequences of occupational exposure of the shipbreaking workers may contribute to the causes behind the geographic shift. The reappearance of the topic demonstrates a time lag between the actual start-up of the work in developing countries and scientific attention on social and environmental issues. For example, shipbreaking in Bangladesh started in the early 1980s (Rahman and Mayer 2015), and literature on the issue started to appear two decades later (Figure 3).

$4 a$

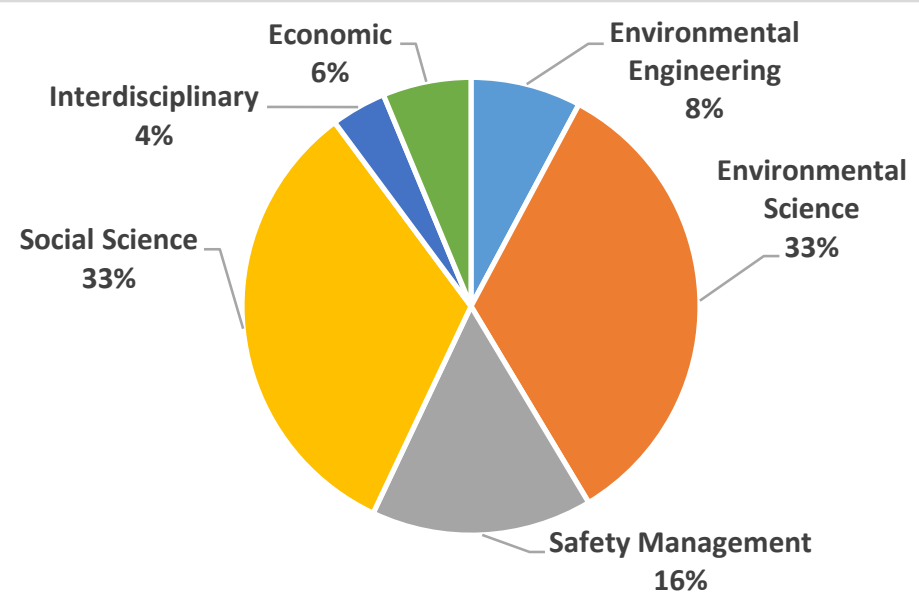




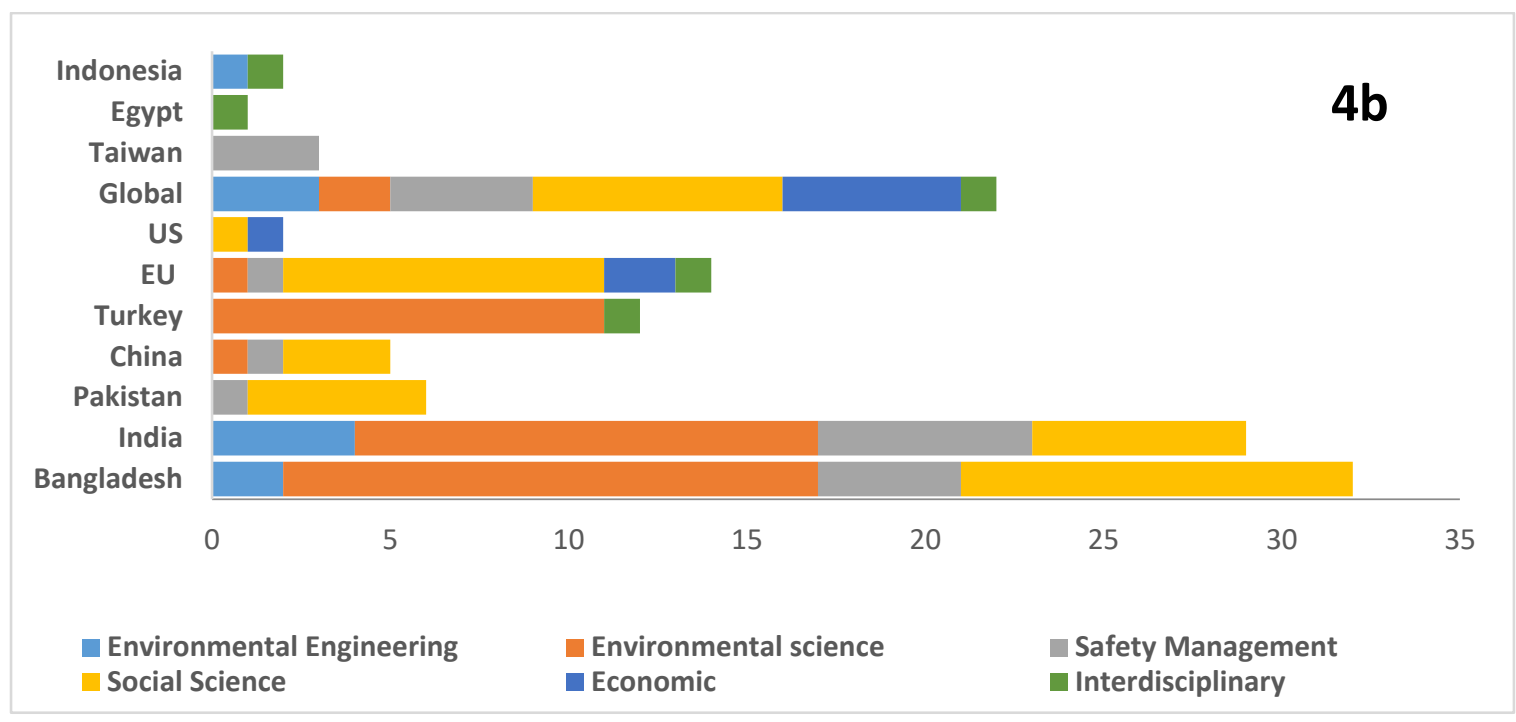

Figure 4: Shipbreaking research by discipline (a) and nation (b).

Figure 4a illustrates the disciplinary representation of the shipbreaking research. Social Science studies (excluding economic analyses), including a substantial number of qualitative ethnographic studies, represent the largest category of focus, accounting for $33 \%$ of all studies. Environmental Science studies also represented $33 \%$ of the total number of papers, while Environmental Engineering accounted for only $8 \%$ of literature. Safety Management shares $16 \%$, while Economic discipline shares only 6\%. Studies that encompassed more than one disciplinary boundaries were few; they represented less than five percent of the studies on SBI.

Figure $4 \mathrm{~b}$ further breaks down the disciplinary boundaries by country. India and Bangladesh share similar number of Environmental Science, Social Science, and Environmental Engineering studies, with pollution assessment as a primary focus, while studies in Turkey exclusively focus on pollution assessment. Papers that viewed this industry from global perspective contain most publications that fall in the Social Sciences, and none from Environmental Science, which is a major gap in the field. In addition, it is noteworthy that the total number of papers by country was correlated to the relative size of each country's shipbreaking activities except Pakistan and China (Figure 5). 


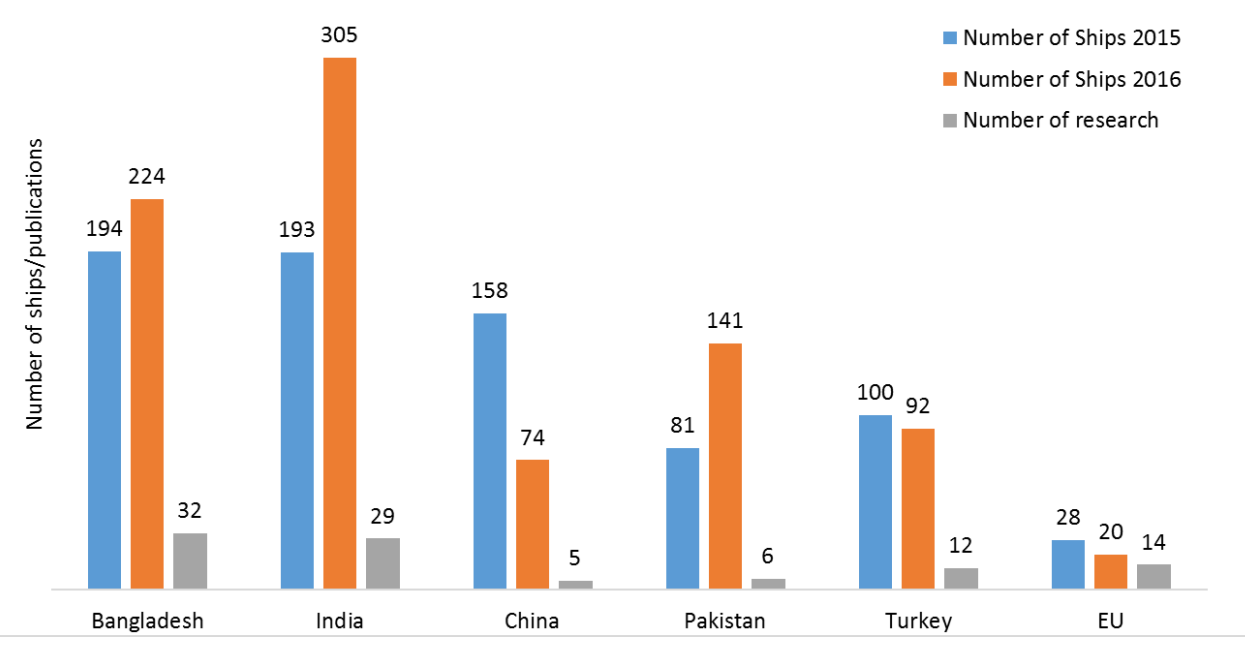

Figure 5: The number of end-of-life ships dismantled in 2015 and 2016 and the number of peer reviewed papers published until April 2018 by country. Shipbreaking data from the NGO shipbreaking platform. The number of publications on the US (2), Global scale (22) and other countries (6) that are not shipbreaking countries are not included in this figure.

\subsection{Dimensions of Sustainable development:}

There were only 5 publications which discussed more than one dimension of sustainability and were categorized as interdisciplinary (Neser et al. 2008, Welaya et al. 2012, Choi et al. 2016, Devault et al. 2017, Ko and Gantner 2016). Likewise, a critical shortage of papers on economic dimensions of sustainability was evident; only 8 publications published out of 128 (McKenney 1994, Nandeswar and Creese 2003, Knapp et al. 2008, Kagkarakis et al. 2016, Kusumaningdyah et al. 2013, Karlis and Polemis 2016, Schøyen et al. 2017, Yin and Fan, 2018) (Figure 6).

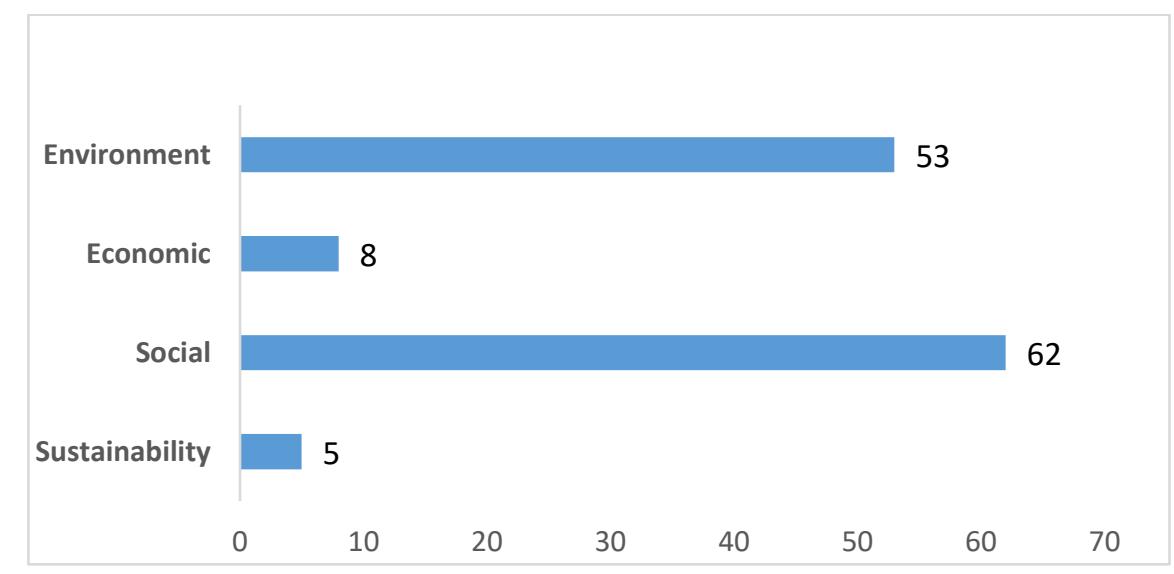

Figure 6: Dimensions of sustainability addressed in selected papers. 


\subsection{Review structure:}

Tree map of 100 most frequent words provide a hierarchical structure of shipbreaking research (Figure 7). The environment is more frequently mentioned than the other two social and economic bottom lines, with the economic term the lowest. The terms that represent environmental dimension are: environment, pollution, waste, coastal/marine, soil, pollution, assessment, concentration, asbestos and heavy metals, while social dimension is represented as hazardous, workers, health, work, safety, management, and risk. The economic sustainability is represented as value, market, business. Scale is identified by the terms "international" and "global" followed by "national "and "local." The most frequent country name appeared is Bangladesh followed by India, Pakistan, China and Turkey, testifying level of shipbreaking activities and demonstrating the suitability of the tree map as an inductive process for the structural configuration and analytical framework in a literature review. It is evident that stakeholders/actors are less attended in this approach of content search. The most noteworthy appearance is the "owners" as the key stakeholders, signifying both shipowners and yardowners connotation.

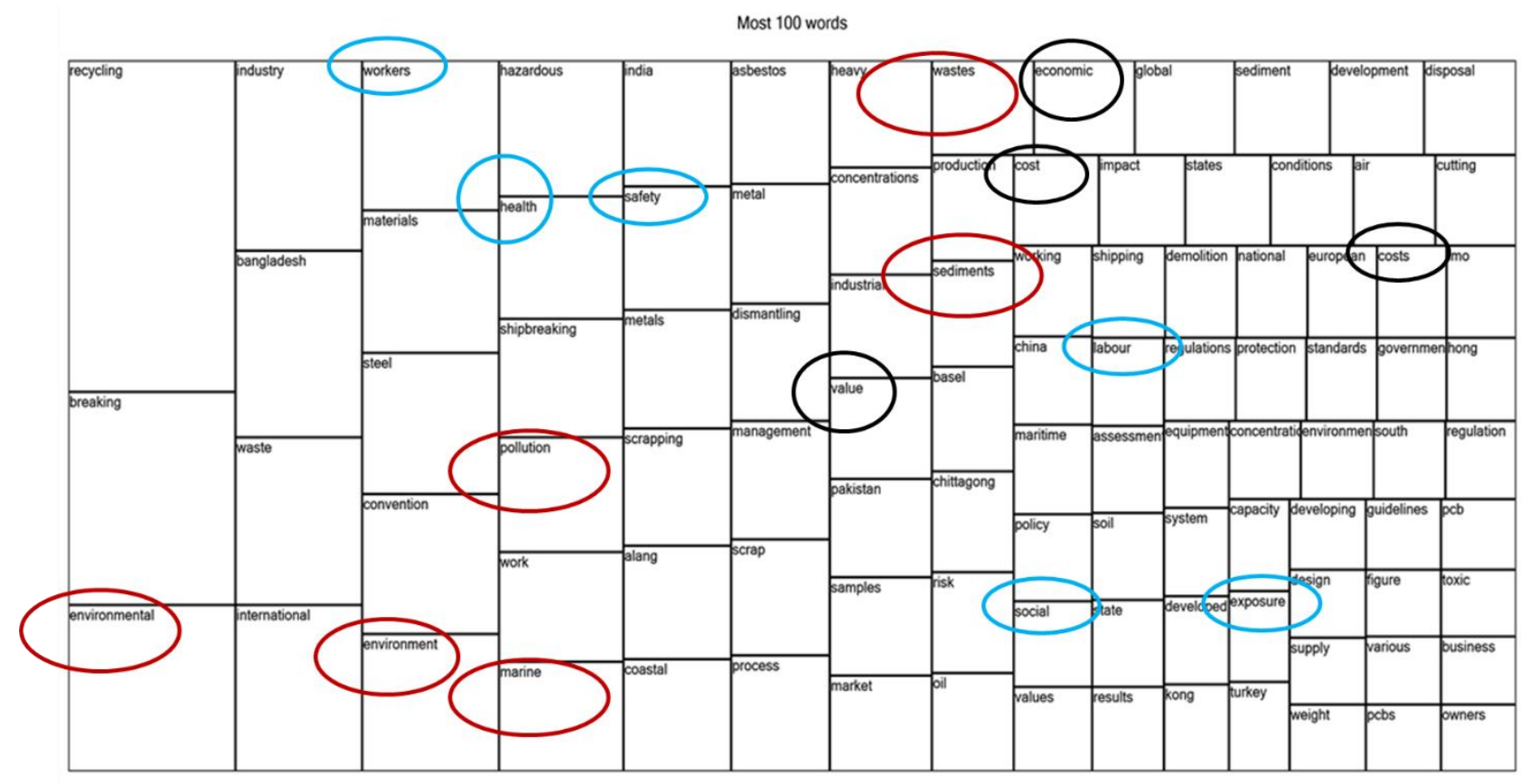

Figure 7: Tree map of 100 most frequent words in Nvivo, with red marked as environmental, Blue as Social and Black as economic. 


\subsection{Discussion:}

\subsection{CBB as a core process impact (environmental)}

4.1.1. Core focus on pollutant estimation establishes environmental adversaries

Out of thirty-eight Environmental Science papers, twenty-four articles focused on pollution assessment revealed strong tendency to identify pollution potentials of the shipbreaking industry. These studies encompass the nature and type of pollutants, polluting areas and medium, seasonal impact variation and distribution. Most of the literature estimated the concentration of common water and air pollutants such as oil, heavy metals, asbestos and persistent organic pollutants (Reddy et al. 2003, 2004 and 2005, Patel et al. 2012, 2013 and 2014, Shah et al. 2015, Siddiquee et al. 2009, Sharifuzzaman et al. 2016, Khan et al. 2017). The approach found concentration above threshold values, impacting coastal ecosystems and risking community livelihood. Most of the major shipbreaking nations including India, Bangladesh, Pakistan and Turkey have conducted pollution assessment research (Islam and Hossain 1986, Neser et al. 2008, 2012a, 2012b, Kacar and Kocyigit 2013, Aktaruzzaman et al. 2014, Kibria et al. 2016).

\subsubsection{Actual waste content modelling is difficult to obtain}

Pollution assessment studies, however, fail to estimate the actual waste content and the proportion that is released into the environment. Few studies have focused on estimating the actual waste content in the ships, due to uncertainty and wide variation by ship type and age (Carvalho et al. 2011, Hiremath et al. 2015, Jain et al. 2016). Actual waste content based on different types of ships was estimated to be $0-3 \%$ by weight in Carvalho et al. (2011) based on five different ship types, $2 \%$ in Jain et al. (2016) based on a bulk carrier, 5-10\% in Demaria (2010) and 6\% in Sujauddin et al. (2015). Jain et al. (2016) provides a material stream flow model for bulk carrier that can be used for material estimation in other ships. Structural organization and material content make it difficult to obtain waste content data and their impacts (Carvalho et al. 2011, Du et al. 2012, Jain et al. 2016). Hossain (2018) estimated waste factor (average $1 \%$ ) and asbestos factor $(0.1 \%)$ of five types of ships dismantled in Bangladesh, with reusable waste percentage around $50 \%$.

Thus, it can be said that waste estimation is partially done with some detail on waste quantity (Sarraf et al. 2010), waste factor (Hossain 2018), model development (Jain et al. 2016). But 
the variation based on ship type and age is required to be more comprehensive that can represent ships of all types and categories.

Ambiguity of pollutant assessment is recently recognized (Barua et al. 2019) and impact assessment based on actual waste release is getting increasing attention. Life-cycle-based impact assessment is conducted by Ko and Gantner (2016), Rahman et al. (2016), Choi et al. (2016) and Ko et al. (2015). Rahman et al. (2016) found that impact occurred by the release of waste directly to the surrounding is minimal and that most impact is found to be related to the downstream rerolling mills due to energy consumption. These studies provide evidence that pollution assessment should be accompanied with an additional level of inquiry such as source apportionment and waste-based impact modelling (Carvalho et al. 2011).

\subsubsection{Interdisciplinary studies begin to appear}

Some recent shift is observed in understanding actual waste discharge and identifying tradeoffs among the social, economic and environmental dimensions. The major attempts to identify and separate sources of pollutants diagnosed in coastal soil, water and air were taken by Aydin et al. (2014) and Kara et al. (2014) in Turkey. Similarly, in Bangladesh, environmental impacts were recorded in different cities, one around shipbreaking industry and the other without shipbreaking, to understand the share of pollutants that are due to the shipbreaking (Kibria et al. 2016). Disciplinary trade-offs are also investigated in several articles: local environment vs local economic benefits (Ko et al. 2015), adjusted ecoefficiency (Ko and Gantner 2016), environmental impacts and occupational risks (Deshpande et al. 2012), dry-dock or sail-in berth method in China (Du et al. 2017), cost-benefit and life cycle assessment approach (Choi et al. 2016). This source-specific pollutant estimation and trade-off focus may provide nuance environmental understanding of the context in which shipbreaking activities are performed.

NGOs and other environmental experts are quite critical about the beaching method and opine that no improvement of environmental metrices is possible unless shift from beaching to other recycling process (dry dock and alongside) occurs. So far there is no alternative for beaching. South Asian nations have been practicing beaching that gives them a competitive advantage over other developed countries - an important aspect that make it economically feasible in the south Asian nations. Most sustainable options are dry dock practiced in developed countries, but those are very expensive and cannot be practiced in 
developing countries in the short term. Turkey practice alongside which is less expensive than dry dock but difficult to manage for bigger ships.

\subsection{CBB as a process impact (social)}

\subsubsection{Process related vulnerability due to giant structure}

Shipbreaking involves process risk of explosions due to the presence of toxic gases, which is followed by falling from height during cutting large sections. The life-threatening accidents happen because of the giant structure of the ships and lack of proper layouts in the ships so that cutters can anticipate the dangers (Hossain et al. 2008).

Workers face three types of process related risks: occupational hazards with immediate consequences such as accidents and injuries; short-term exposure to hazardous materials via the inhalation of toxic fumes during cutting (infecting respiratory systems); and long-term consequences that appear after retiring from dismantling activities. Metal cutting activities dominate $71 \%$ of the total labor force. These activities pose risks to cutters and helpers due to inhalation of fumes released during cutting (Deshpande et al. 2013, Rahman et al. 2016). Most of the studies focused on occupational hazards and short-term exposure because the damage is relatively easy to determine and noticeable (Andersen 2001, Hossain et al. 2016).

Hazards-specific exposure assessments have been conducted in several areas: asbestosis (Courtice et al. 2011, Wu et al. 2015), lead exposure (McCallum 1968, Tola and Karskela 1976, Nosal et al. 1990), paint exposure (Engstrom et al. 1990), metal exposure during cutting (Ho et al. 1989), and long-term mortality among shipbreaking workers in Taiwan (Wu et al. 2013).

4.2.2. Management related vulnerability due to unwillingness to apportion cost for workers safety

Working conditions and worker rights mostly revolve around medical facilities, safety equipment, and accident and injury management (Andersen 2001, Sahu 2014). Low overtime, low bargaining power, traditional cutting technology and labor migration are widespread in the shipbreaking yards (Andersen 2001). Labor unions are weak in India and Pakistan due to (1) labour unions are 'surprisingly' inactive to raise workers voice and (2) a 
good number of workers are reluctant to participate or are willing only to deal with minor issues due to fear of losing jobs (Sahu 2014). In Bangladesh, it is found that majority workers prefer proper medical facilities as their first preference while place trade unions in second (Hossain et al. 2008). Recent studies found that workers position is tricky and mostly dictated by high preferences for employment while yard owner and NGOs produce counter narratives, that fail to understand actual worker interests (Rahman et al. 2018). Most of the workers remained untrained due to the temporary nature of the works, with less than $15 \%$ of the workers are permanent in Bangladesh yards (Hossain et al. 2008). In Bangladesh, the managers do not supply personal protective equipment while in India, managers provide improper equipment (Sahu 2014, Rahman et al. 2018).

The Taiwanese studies that establish a connection between asbestos exposure and cancer detection recommended continuous monitoring of workers for early detection of asbestosis and cancer (Wu et al. 2013, 2015). Symptoms develop over time and thus require continuous health surveillance throughout a worker's life (Ho et al. 1989). It is noteworthy that similar studies have not been conducted in the current shipbreaking nations (except Deshpande et al. 2012 and Courtice et al. 2011), signaling a critical gap in our understanding of impacts on workers' long-term health in developing countries. Pakistan surpasses India and Bangladesh in terms of application of heavy machinery, the existence and functioning of labor unions, and compensation enforcement for accidents and injuries (Iqbal and Heideggar 2013, Sahu 2014). World Bank study showed that to comply with international standards, an additional 10-15 dollars per LDT (as opposed to 62 dollar profit per LDT ) is required to invest over a ten year period of time (Sarraf et al. 2010).

\subsubsection{Context related vulnerability due to wider socio economic status}

Socioeconomic context (awarness level, climate, unemployment situation, stakeholder hostility, poor governance) remain one of the challenges to improving sustainability in shipbreaking industry (Cairns 2007, Cairns 2014). Awareness level among the workers in different countries remains low. For example, in Bangladesh, shipbreakers are not aware at all about asbestos itself (Tola and Karskela 1976). Three Asian nations (especially Bangladesh) sell asbestos to local communities, demonstrating the low awareness of its dangers among the localities that are using them (Ahmed and Siddiqui 2013). The high unemployment rate in the shipbreaking nations force workers to accept work of any level of risk (Cairns 2007). Some workers opine that workers cannot wear protective equipment due to hot and humid weather 
and not conducive for muddy beach conditions. In addition, conflict of interest exists between yard owners and NGOs, that resulted into entry restrictions to yards for visitors. Mafia like structures may not exist anymore as NGOs become influential in articulating social and environmental issues and drawing attention to policy makers (Rahman et al. 2018). In addition to poor governance context, softer attitude from the government officials is also noted as the officials are of the opinion (opposite to NGOs) that economic development should be prioritized over environmental care in the developing countries (Rahman and Mayer 2016).

While poor working conditions have dominated conversations about shipbreaking from NGOs, critical understanding of welfare adjusted employment benefits that are supposed to trickle down to education, living standards, medication in long-term injuries remains unclear. Welfare adjusted income index characterized by health, family expenditure, education and migration against income is critical for a successful bottom-up policy formulation.

\subsection{Emerging $P B$}

\subsubsection{Process related vulnerability related to international territory}

Growing literature seems to connect the shipbreaking phenomenon to broader network beyond the immediate process impact. Frey (2015) compares it with core-periphery system where developed countries dump and peripheral countries harvest. In another word, some view that the shipbreaking systematically fits within NIMBYism and WIMBYism, in that developed countries does not want to deal with the economically unattractive vessels while due to socioeconomic compulsion, developing countries found this as a resource. Gregson et al. (2016) showed that the world system is quite stable in that disruption caused by any imposed bans might worsen social conditions in the host countries.

The beginning of the EoL ship management decisions is largely underpinned by the fact that shipowners gain about additional 100-200 USD per LDT when they send ships to south Asian nations. This is a huge monetary incentive that historically shifted shipbreaking from developed countries to developing countries and, unless addressed, may potentially continue to challenge or undermine initiatives for improvement of south Asian facilities. Since improvement requires some form of investment that may reduce competitive advantage, leading to a shift of this activity to a new place or region that maintain shipowner monetary 
incentives. A traditional CBB approach cannot break this business link unless a comprehensive approach is undertaken. Namely, shipowner, International supervisory body, Yard owner and NGOs need to discuss together and find a common ground that serves interests of all parties. Although shipowners of the developed countries seem to acknowledge this fact and are willing to contribute to the EoL ship management services by the south Asian nations, there is no study that comprehensively devise ways to correct this market failure.

In contrast, significant uncertainty of profit making by the yard owner is pointed out due to inconsistent market behavior. For example, secondary scrap price widely fluctuates in the world market; The significant time lag between when a ship is purchased and when the recovered scrap is sold is reported to be causing loss to yard owners. The net profitability (16\% for Bangladesh and 12\% for Pakistan) reported in Sarraf et al. (2010) requires adjustment with the market uncertainty. However, such uncertainty and impact of this on profitability is difficult to quantify and thus offer no real ground for further assessment of critical social and occupational issues. Perhaps, the lack of such critical studies did not convince the policy makers to seriously consider the capacity building support for the developing country facilities.

\subsubsection{As a management approach through policy formulation}

The Basel Convention and the Hong Kong International Convention on the Safe and Environmentally Sound Recycling (HKC) are important policies that regulate the shipbreaking industry, along with the latest European Ship Recycling Regulations (ESRR). Policy publications mostly focused on national and international policy gaps and challenges (Alam and Faruque 2014, Zhang and Chang 2014, Alcaidea et al. 2016, Rahman and Mayer 2016), technical and financial incentive structures (Rahman and Mayer 2016), and international regulatory loopholes (Alcaidea et al. 2016). These regulations are guided by principles such as "polluter pay principle", "proximity principle" and "extended producer responsibility". One issue with the application of Basel convention in EoL ships is that Basel convention is applied to the hazardous waste in general, but not to the ship. The problem is expected to be resolved by the Basel ban amendment, in which any hazardous waste is banned irrespective of whether it is just a part of a thing or the thing itself (Karim 2015). Along the line and more particularly, the dilemma is partly covered by the formulation of ESRR that forbids all EU ships from being dismantled in substandard yards, as per proximity principals. 
On the other hand, the HKC relies on the schematic arrangement of wider network and processes including detailed procedural guidelines, from dismantling decisions by shipowners to dismantling ships in yards, through the deployment of proper documentation, certification and inspections (Karim 2015, Rahman and Mayer 2016, Alcaidea et al. 2016). The approach seems perfunctory, as it perceived shipbreaking problems as derived from certification problem. In contrast, national level policies are quite stringent but remained largely unimplemented (Sahu 2014, Rahman and Mayer 2016).

All three policies do not seem to address the cash based informal transaction occurred when a ship is sold in international marketplace. Practices of selling ships at their EOL occur in the international sea: loopholes exist which allow owners to reflag EOL ships before beaching, relaxing ship owner responsibilities and boosting their profit margin (Sarraf et al. 2010, Alcaidea et al. 2016). By selling ships to a substandard yard compared to a standard yard in Turkey, shipowner earns about 200 USD per LDT- an economic incentive that is mostly enjoyed by the upstream actors and dictates the entire flow (Schøyen et al. 2017).

Flag state loophole is considered to one of the important barriers for shipbreaking sustainability. Two ways vessels are registered: closed registration and open registration. Close registration are usually the owning nations that flag its own vessels whereas open registration is usually done in foreign nations that flag the vessels. Recent data reveal that about $68 \%$ vessels are open registered, meaning that they use the foreign country flag and the trend is increasingly observed from $41.5 \%$ in 1989 to $73 \%$ in 2014 . The reasons of the open registry are the reduction of operating costs (crew cost), avoid strict regulations, escape national taxation and hide identities (Yin et al. 2018). The use of open registry is, therefore, increasingly for economic reasons, occurred predominantly in operational stage, but may also be linked with EoL stage. One study that exclusively focuses on whether the change of flag occur at the end of life stage demonstrates that flagging under open registry is causing the damage, referring to the rate of flag change that increases from $11 \%$ to $18 \%$ within the last few years of ship demolition (Alcaidea et al. 2016). Rahman and Kim (2019) showed that the flagging is not so much linked to substandard destinations as it is with the size of the ships. Because the substandard nations can recycle bigger ships, it is found that bigger ships, despite closed registry, are found to be recycled in substandard nations, in contrast, smaller ships, despite the open registry, are recycled in standard yards. This indicates that the discussion of flag state in the shipbreaking realm is only partially relevant or are marginally (and unintentionally) influenced. Although researchers in the shipbreaking areas associate this as a 
major cause of substandard recycling, the issue needs to be further investigated. This misunderstanding may stem from focusing exclusively on last stage of ship life cycle.

Many studies have mentioned the necessity of establishing funding scheme, but few have gone deeper of this matter and offered detail analysis of the types of funding scheme available, barriers to implement the scheme and ways to overcome them (Rahman and Mayer 2016). Alam and Faruq (2014) mentioned the Technical Co-operation Trust Fund - A funding mechanism under Basel convention is largely voluntary and the contributions collected annually are smaller than the expenditures required for its operations. Rahman and Mayer (2016) mentioned about deposit - refund system, mimicking funding mechanism of the sodacan recycling process. The lack of research on detail funding procedures may be due to conflict of interest of global sustainability (only two impact categories climate change and ozone depletion are global, and the rest are local).

\subsubsection{As an emerging global production /recycling context}

This aspect of shipbreaking is pioneered by the Gregson and colleagues $(2011,2013)$. They argue that shipbreaking phenomenon is emblematic to a new form of production system, arising from the back end of the product chain, namely the recycling activities that occur far from the origin of the product. This back-end activity added value to the 'waste' quite creatively, that has been discarded by the western consumers and perceived to be as economic burden and environmental hazard. Some of the 'waste' after being sorted and treated find their way back to the product chain of the developed countries, leading to a new context of resource supply, in that a reverse internationalization is initiated through the extension of 'waste' life and expected to grow in the near future.

Although this back end activity is often performed in less-than-standard facilities, they argue that this phenomenon, wherever it is occurring - poses vulnerability across space and time - be it in developing countries or developed countries (labor migration in recycling industry within EU) (Gregson et al. 2011, 2014). This studies thus point to the fact that the activity is inherently risky and thus a comprehensive understanding to improve aspects that are challenging is required to put in place. These studies lay basis to think on local, social and ecological context of production and consumption, intertwined across scales and levels. 


\subsection{Strength of shipbreaking research}

\subsection{Pollution assessment studies articulate strongly the adverse impact on environment}

The literature on environmental dimensions demonstrated that shipbreaking activities discharge pollutants to coastal ecosystems and aimed to highlight environmental impacts for policy makers at national and international levels. All shipbreaking nations have conducted environmental pollution research to identify sources of pollutants, with varying levels of precision (Aydin et al. 2014, Kara et al. 2014), and impact assessments (such as life cycle assessment) at the process level (Rahman et al. 2016, Deshpande et al. 2013). In addition, recent efforts to identify waste content inside EOL ships signifies a shift to more detailed environmental data that can be used to formulate more effective policies (Jain et al. 2016, Hiremath et al. 2015).

\subsection{A clear direction from $C B B$ to $P B$}

CBB approach has identified environmental and social adverse impacts ensued from shipbreaking activities. This approach tends to highlight exclusively on yard-based activities and the accompanied environmental discharges, workers exposures, and their impacts, working conditions management and process-based policy formulations. CBB also shifts slightly, in recent studies from impact identification to more nuanced understanding of economic and environmental trade-offs, source-specific pollutant and ship wise waste estimation. CBB also identified peripheral relationship on the impact reduction, for example, design for disassembly approach of the shipbuilders. However, in CBB approach, some gaps remained unaddressed: short/ long-term impacts of exposure on worker health, injury adjusted workers income and absence of improvement pathways (Cairns 2007).

In $\mathrm{CBB}$ and $\mathrm{PB}$ interface, several studies discussed on environmental justice, policy formulation and lack of implementation as well as the cultural contingency that demonstrate challenges in identifying approach towards TBL sustainability. For example, HKC and ESRR successfully acknowledged PB in dealing with upstream processes (certification, green passport, checks and audits, technical assistance among others) but those are largely mechanistic without proper understanding of the key challenges in PB. For example, one may consider technical assistance as a superficial charity approach without redressing the fundamental problems of stakeholder's commitment and interests (value appropriation conflicts across supply chains, economic drivers and competitiveness, cultural legacy and envisioning challenges) (Figure 9). 


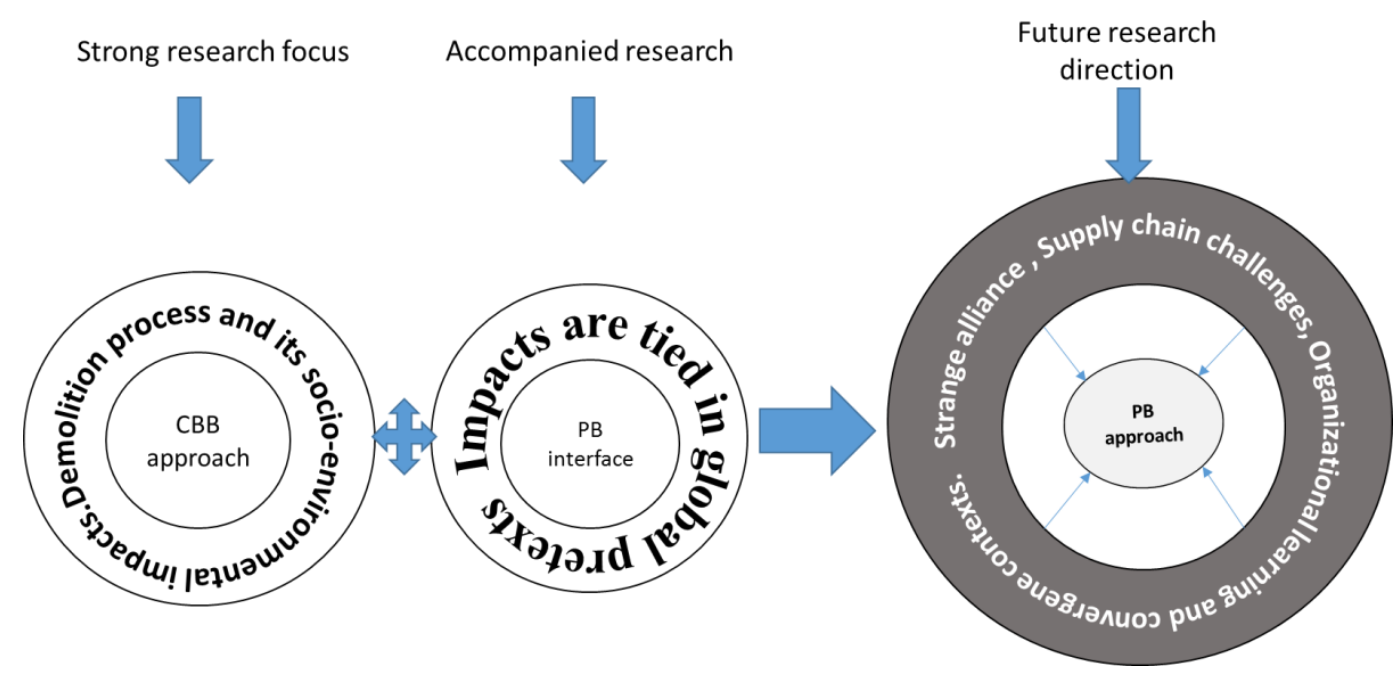

Figure 9: $\mathrm{CBB}$ and $\mathrm{PB}$ approach in shipbreaking

\subsection{Strange alliance formation is emergent in the current studies}

Several stakeholders are relevant to shipbreaking, particularly NGOs are quite vocal in terms of environmental pollution and working conditions. Yard owners remained scary to wide variation of profitability - an issue that is not quite addressed in the NGO suggestions. The consequences are entry restrictions to yards against NGOs surveillance. This confrontational relationship has been identified in several studies: for example, Sujauddin et al. (2017) termed as "confronting relationships", Rahman et al. (2018) as "discursive conflict" and Crang et al. (2013) as "unembedded network". Several studies have highlighted the need to transform this hostile relationship to partnership and participation. Although, different mode of participation is mentioned, for example, NGOs and government collaboration (Zafar Ullah 2016), partnership among multi stakeholders (Courtice 2011), role coordination (Sahu 2014) and recycling nations alliance (Sahu 2014, Rahman and Mayer 2016), a collaborative environment is essential as the disjointed effort from stakeholders leads to ineffective goal settings and perpetuate the disparity (Figure 11). 


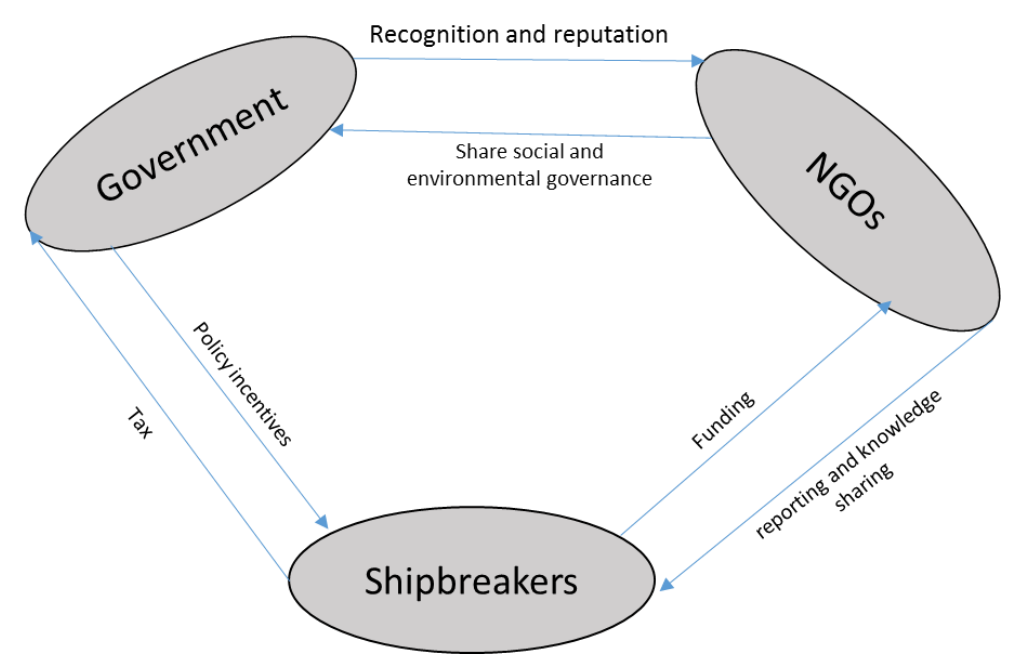

Figure 11: Strange alliance formation context among government, NGOs and yard owners.

\subsection{Shortcomings of the existing research:}

- $\quad C B B$ studies fall short of integrating system thinking and development of social, environmental and economic metrics and trade-offs.

It is evident so far that shipbreaking research represents conventional disciplinary boundaries and ignores synergistic interactions, conflicting social goals and trade-offs. System integration enables coupling of human and ecological systems in order to understand system complexity and enhance synergies among factors (Liu et al. 2015). Shipbreaking generates impacts across scales (local, national and global), dimensions and organizational levels - part of the complexities are only introduced in Kusumaningdyah et al. (2013) but more rigorous studies detailing matrices in all three dimensions are essential. For example, asbestos use threatens yard workers (local impact) but adds to local secondary business including yard owners' income (economic dimension) and reduces environmental waste production (environmental dimension). The business culture, in turn, supports the persistence of EOL ship trade in the international market (global impact). Improving yards is not a goal in itself. For example, facility improvement in China reduced overall business competitiveness, resulting in net negative impacts through leakage effects, which in turn influenced yard owners' decisions in other countries (Du et al. 2017). Shipbreaking income provides economic security but may reduce family solidarity as a result of labour migration and threatens health through exposure to occupational hazards (Figure 9). 


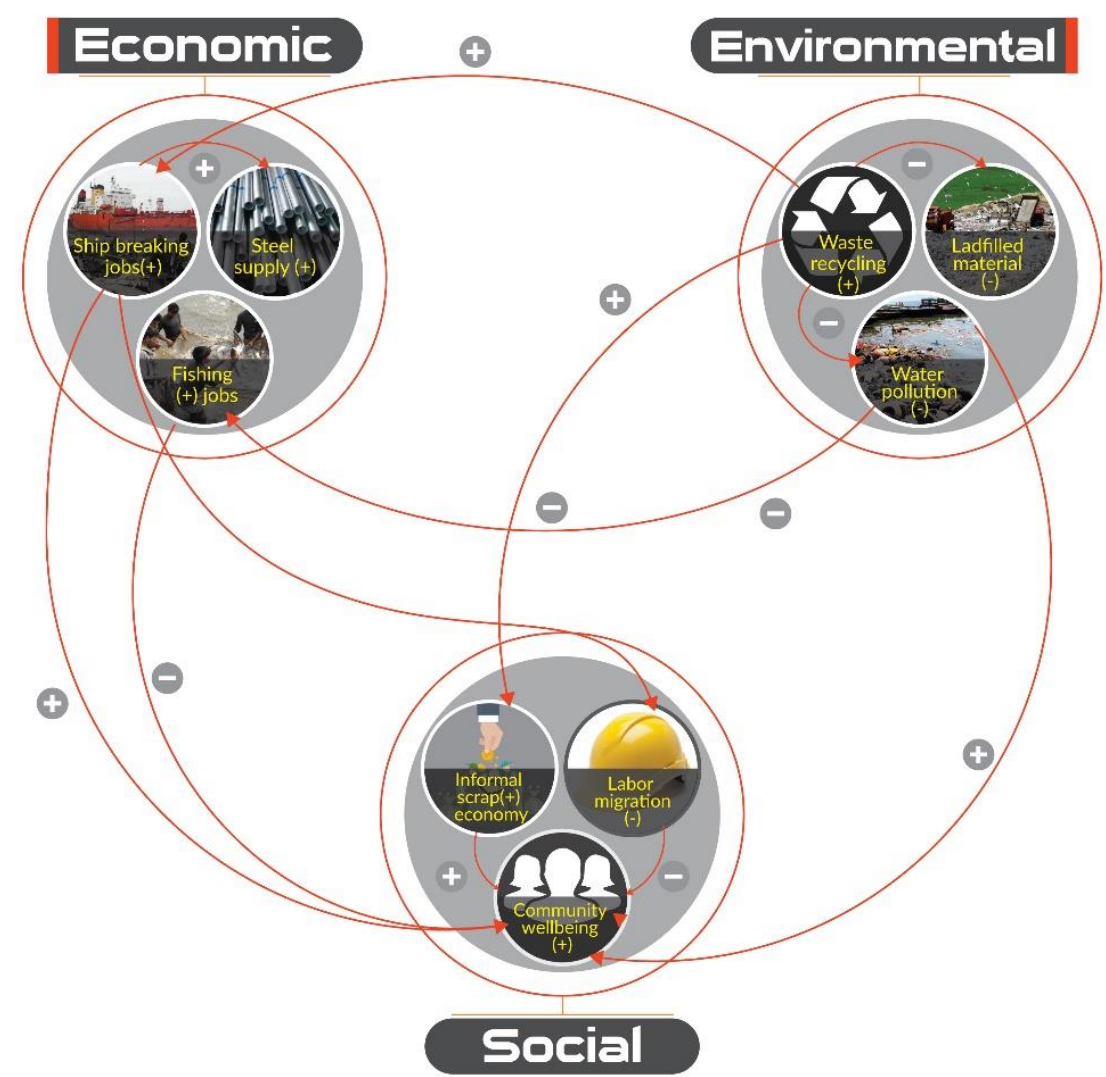

Figure 9: Interaction trajectories among shipbreaking variables at the national level; $(+) /(-)$ inside the parenthesis () represents the nature of the variables; $+/$ - inside the circle alongside the arrow represents synergistic effects.

- Developed countries' contributions to and responsibilities for shipbreaking.

Choi et al. (2016) examined whether shipbreaking is still feasible in US, but no studies have looked at any other former shipbreaking countries. Only Rahman and Mayer (2016) discuss the responsibility that developed countries should bear for improving conditions at shipbreaking yards in developing countries, following the polluter pays principle. In EU level, a number of facilities have been approved for shipbreaking, which may not support global sustainability (Rahman and Kim, 2019). This raises debate whether proximity recycling would generate more global sustainability. Recently, European commission approved 24 new ship recycling facilities within EU and beyond. This indicates a future trend of how developed countries would go forward to handle the shipbreaking phenomenon.

- Technical assistance and capacity development is under-researched

It is utmost important that further detail is required in terms of different types of funding options available, problems associated with each type and ways to overcome the challenges. In addition, stakeholder assessment is necessary to ensure implications of the funding is 
equitable and does not harm any parties concerned. For example, it is necessary to estimate the cost involved in the upgradation and certification of a recycling yard. Doing so, it needs to be examined if the company upgrading the yards loose competitive advantage? Such effect is already manifested in Chinese yards (Du et al. 2017). In addition, it is also important to examine if shipowners who exact most of the economic gain actually get charged through the deposits or pass the charge to consumers.

- Institutional and social conditions (process, management and context related) are key to ensure TBL sustainability; which are largely neglected

Institutional and policy setting is highly specific to country context. Therefore, it is important to understand how (and to what extent) process, management and context related vulnerability can impede policy and regulatory improvements. This knowledge is key to developing better policies at multiple scales and understanding interactions across scales. Few emerging literatures has been using LCA as a method for environmental quantification including other dimensions to a lesser extent. Social life cycle assessment is not mentioned and applied in any of the literature. This represents a critical gap in objective assessment of social impacts of shipbreaking activities.

- Pakistan and China shipbreaking studies are underrepresented.

While China and Pakistan are among the top five shipbreaking nations and share $23 \%$ and $10 \%$ ship breaking activity by LDT, they are noticeably absent from the ship breaking literature. China introduced modern technologies in their yards and is recognized as a qualified recycler; its successes need to be highlighted to encourage lagging countries to upgrade shipbreaking facilities (Du et al. 2017).

\subsection{Future research: Toward sustainability framework in the developing country recycling:}

I propose a sustainability management framework for the recycling sector of the developing countries. This framework constitutes three boundaries through which an industry of a developing country may be viewed: CBB, emerging PB and Strong PB. CBB focused on immediate process impacts but ignored the external influence structures. In emerging PB, wider geography becomes visible but not strategically organized. For example, capacity assistance is mentioned but not detailed. In strong PB, capacity building and learning of the internal and external stakeholders is emphasized in order to target setting and integrated planning. In this stage, the identification of challenges and formulation of detail strategies are done through active engagement of strange alliances and encompassing attitude and approaches of supply chain actors (Figure 13). 


\section{Strong PB}

\section{Emerging PB}

\section{CBB}

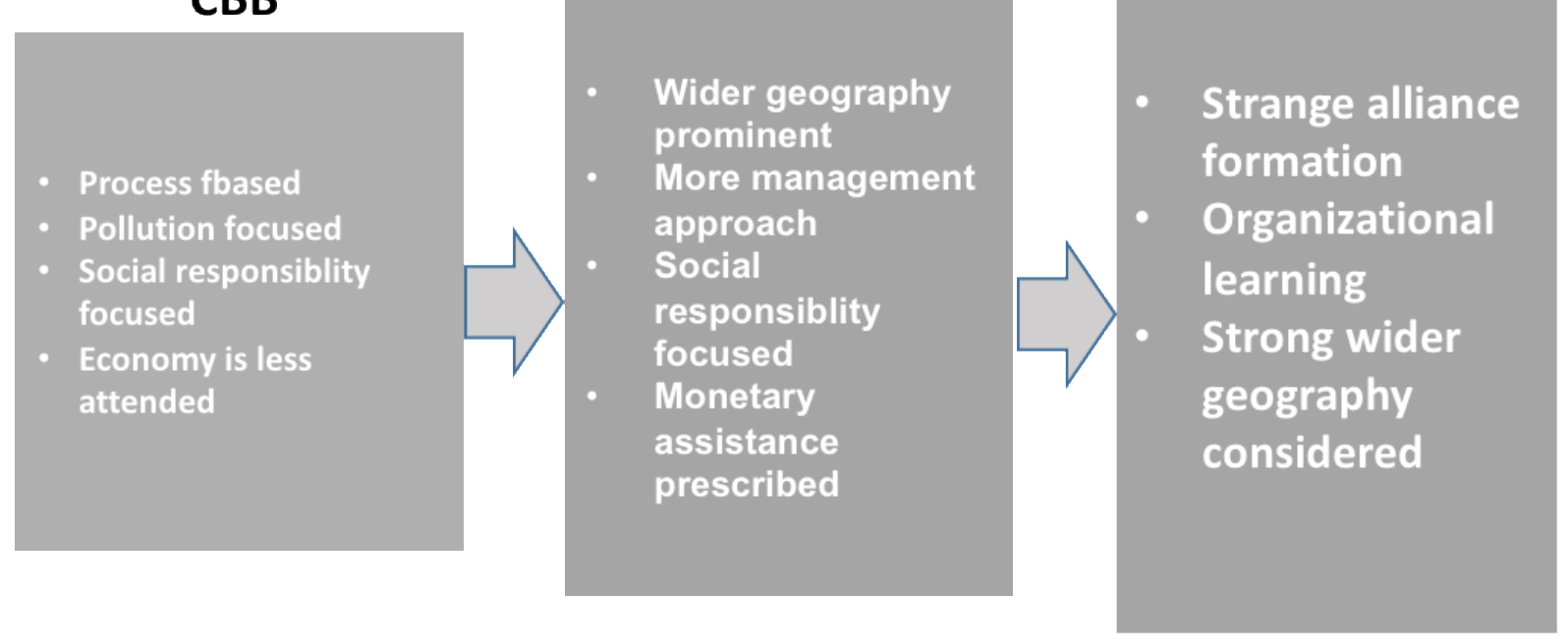

Figure 13: Sustainability management framework for recycling industry in the developing

countries.

Gimenez et al. (2012) shows that environmental initiatives impact on three dimensions of the TBL sustainability while social initiatives only influence two (social and environmental) dimensions. He proposed that financial gain needs to be ensured while social programs are launched. They also proposed that supply chain collaboration - not assessmentbrings positive impact on the attainment of TBL. They proposed that managers need to be aware of financial sacrifices associated with the improved social programs and need to enhance collaboration among the supply chains. Our review supports this view that sustainability in the developing countries need to be integrated critical assessment of TBL matrices and stakeholder's collaboration. This aspect is clearly addressed in our sustainability framework in which CBB is identified with the need to incorporate more nuance assessment procedures and to integrate stakeholders from across the supply chains.

A common framework for the socio-ecological systems sustainability is proposed by Estrom (2009). He points out that in a socio-ecological system, resources depletion occur predominantly due to (1) non communication of stakeholders, (2) diverse stakeholders group and (3) absence of unified rules and regulation for attaining sustainability. He also focused on identification and analysis of complex relationships of the multilevel stakeholders. He identified ten second level variables and discuss their implications on the resource use: Size of resources systems, Productivity of system, predictability of system dynamics, Resource unit 
mobility, Number of users, Leadership, Norms/social capital, Knowledge of SES, Importance of resource to users, Collective-choice rules.

Dao et al. (2011) provided a sustainability framework based on prioritizing financial bottom lines, which consists of four quadrants. These four quadrants outline how a business should streamline its internal and external strategy in future. I analyze these four quadrants in order to evaluate the sustainability status and future pathways for improvement.

I1. As a $\mathrm{CBB}$, strategy to prevent pollution through optimizing operation cost is suggested, which requires careful identification of 'zones of mutual benefits' (Jain et al. 2018). Organizational culture remains as it is despite some studies on occupational hazards and consequences.

I2. As a future $\mathrm{CBB}$, strategies that aim at developing cleaner technologies to address social and environmental issues are suggested. This aspect is complex as the approach may be viable for developed country facilities but not in developing countries as cleaner form of technologies are often not appropriate.

E1. As a PB approach, supply chain integration is suggested and extension of organizational culture that addresses internal and external stakeholders is focused.

E2. As a future PB approach, CBB capabilities need to be improved in all products, processes and supply chains. New vision integrating previously unaddressed issues with stakeholders are prescribed.

Thus it seems that while CBB needs to adopt more rigorous assessment techniques so as to improve objective understanding of the complex matrices. At the same time, extension of system boundary from CBB to PB is required, ensuring stakeholders' collaboration. From the Dao et al.(2011), I can also safely point out that organizational learning is essential with new visions and stakeholders dialogue. Organizational learning here refers to a learning towards new vision that reevaluate the original position (mostly antagonistic) by yard owners and NGOs and reset their visions in order to work together. Through this, it is quite clear that sustainability concerns today are quite complex and, to address these, CBB processes are required to complemented by PB level collaboration and alliance making. 


\subsection{Conclusion:}

The current collection of research covers a few areas very deeply but leaves many gaps within and across disciplines. The papers reviewed here do establish the pollution potential of shipbreaking, but more rigorous studies are required to address source apportionment issues, ship-wise waste content, designing ships with less hazardous materials and easy dismantling techniques, cost distribution and profit sharing, and workers income versus health risks. In addition, shipbreaking phenomenon is emblematic to a new form of transnational industrial governance, in which global production and consumption pattern is increasingly demanding wider network engagement and collaboration. In this review, I have argued that such a boundary $-\mathrm{PB}$ - is increasingly manifested that calls for alliance making rather than collusion and conflict. The reorganization of the stakeholders in PB foster the organizational learning capability of the recycling industry such as shipbreaking and promote global sustainability.

The significance of the finding is that the integration of peripheral conditions in core issues may reduce the level of misunderstanding of the stakeholders from the west when evaluating social and environmental indicators of a recycling industry in the developing countries. The finding may have effect on the issues that lie at interface of sustainability assessment and stakeholder strategies to achieve sustainability. There are other studies that provide similar suggestions of going beyond a business boundary and integrate stakeholder participation (Seuring and Gold, 2013). However, stakeholder participation does not merely resolve issues, when stakeholders bring with them preconceived notions and biased valuations. This needs a commitment from the stakeholders to reorient their preconception based on new understanding and merge towards a unified goal, identified through the formation of strange alliance and effective learning process in organization level (NGOs stance, yard owner business strategies etc.). The barriers along this line are the identification of lead actors that coordinate the alliance formation process and uplift from the narrow understanding of the stakeholders involved. The findings in the real world may bring significant change in both sector level and international level. In sector level, stakeholders would not only be attentive to certainty of economic bottom line of the organization, but also ensure how the economic gain is distributed to improve the social and environmental bottom lines. In international level, challenges for material efficiency concerning the distant recycling will be better understood and addressed. The possible ways of going forward, as discussed in the above, are to develop sophisticated social and environmental matrices and at the same 
time, ensure uniform understanding and active participation of the stakeholder for the management of issues in the PB.

\section{References:}

Abdullah, H. M., Mahboob, M. G., Banu, M. R., \& Seker, D. Z., 2013. Monitoring the drastic growth of ship breaking yards in Sitakunda: a threat to the coastal environment of Bangladesh. Environmental monitoring and assessment. 185(5), 3839-3851.

Ahmed, R., \& Siddiqui, K., 2013. Ship breaking industry in Pakistan- problems and prospects. International Journal of Management. IT and Engineering. 3(9), 140.

Aktaruzzaman, M., Chowdhury, M. A. Z., Fardous, Z., Alam, M. K., Hossain, M. S., \& Fakhruddin, A. N. M., 2014. Ecological risk posed by heavy metals contamination of ship breaking yards in Bangladesh. International Journal of Environmental Research. 8(2), 469-478.

Alam, S., \& Faruque, A., 2014. Legal regulation of the shipbreaking industry in Bangladesh: The international regulatory framework and domestic implementation challenges. Marine Policy. 47, 46-56.

Alcaidea, J. I., Piniella, F., \& Rodríguez-Díaza, E.,2016. The "Mirror Flags": Ship registration in globalised ship breaking industry. Transportation Research Part D: Transport and Environment. 48, 378-392.

Alcaidea, J. I., Rodríguez-Díaz, E., \& Piniella, F., 2017. European policies on ship recycling: A stakeholder survey. Marine Policy. 81, 262-272.

Andersen, A. B., 2001. Worker safety in the ship-breaking industries. International Labour Office, Geneva.

Austin, J. E. (2010). The collaboration challenge: How nonprofits and businesses succeed through strategic alliances (Vol. 109). John Wiley \& Sons.

Aydin, Y. M., Kara, M., Dumanoglu, Y., Odabasi, M., \& Elbir, T.,2014. Source apportionment of polycyclic aromatic hydrocarbons (PAHs) and polychlorinated biphenyls (PCBs) in ambient air of an industrial region in Turkey. Atmospheric Environment. 97, 271-285. 
Basha, S., Gaur, P. M., Thorat, R. B., Trivedi, R. H., Mukhopadhyay, S. K., Anand, N., ... \& Jha, B., 2007. Heavy metal content of suspended particulate matter at world's largest ship-breaking yard, Alang-Sosiya, India. Water, Air, \& Soil Pollution. 178(1), 373-384.

Boström, M., Jönsson, A. M., Lockie, S., Mol, A. P., \& Oosterveer, P., 2015. Sustainable and responsible supply chain governance: challenges and opportunities. Journal of Cleaner Production, 107, 1-7.

Cairns, G., 2007. Postcard from Chittagong: wish you were here?. Critical perspectives on international business. 3(3), 266-279.

Cairns, G., 2014. A critical scenario analysis of end-of-life ship disposal: The "bottom of the pyramid" as opportunity and graveyard. Critical perspectives on international business. 10(3), 172-189.

Carter, C. R., \& Rogers, D. S., 2008. A framework of sustainable supply chain management: moving toward new theory. International journal of physical distribution $\&$ logistics management, 38(5), 360-387.

Carvalho, I. S., Antão, P., \& Soares, C. G., 2011. Modelling of environmental impacts of ship dismantling. Ships and Offshore Structures. 6(1-2), 161-173.

Chang, Y. C., Wang, N., \& Durak, O. S., 2010. Ship recycling and marine pollution. Marine pollution bulletin. 60(9), 1390-1396.

Chatterjee, P. ,2013. The Darker Side of Western Modernity: Global Futures, Decolonial Options. Walter D. Mignolo. Durham, NC: Duke University Press, 2012. xxxvii+ 408 pp.

Choi, J. K., Kelley, D., Murphy, S., \& Thangamani, D., 2016. Economic and environmental perspectives of end-of-life ship management. Resources, Conservation and Recycling. 107, 82-91.

Courtice, M. N., Demers, P. A., Takaro, T. K., Vedal, S., Ahmad, S. A., Davies, H. W., \& Siddique, Z., 2011. Asbestos-Related Disease in Banlgadeshi Ship Breakers: A Pilot Study. International journal of occupational and environmental health. 17(2), 144-153.

Crang, M., Hughes, A., Gregson, N., Norris, L., \& Ahamed, F., 2013. Rethinking governance and value in commodity chains through global recycling networks. Transactions of the Institute of British Geographers. 38(1), 12-24. 
Dao, V., Langella, I., \& Carbo, J. (2011). From green to sustainability: Information Technology and an integrated sustainability framework. The Journal of Strategic Information Systems, 20(1), 63-79.

Demaria, F., 2010. Shipbreaking at Alang-Sosiya (India): an ecological distribution conflict. Ecological economics. 70(2), 250-260.

Demaria, F., 2016. Can the Poor Resist Capital? Conflicts over 'Accumulation by Contamination'at the Ship Breaking Yard of Alang (India). In: Nature, Economy and Society (pp. 273-304). Springer, India.

Deshpande, P. C., Kalbar, P. P., Tilwankar, A. K., \& Asolekar, S. R., 2013. A novel approach to estimating resource consumption rates and emission factors for ship recycling yards in Alang, India. Journal of Cleaner Production. 59, 251-259.

Deshpande, P. C., Tilwankar, A. K., \& Asolekar, S. R., 2012 . A novel approach to estimating potential maximum heavy metal exposure to ship recycling yard workers in Alang, India. Science of the Total Environment. 438, 304-311.

Devault, D. A., Beilvert, B., \& Winterton, P., 2017. Ship breaking or scuttling? A review of environmental, economic and forensic issues for decision support. Environmental Science and Pollution Research. 1-34.

Du, Z., Zhu, H., Zhou, Q., \& Wong, Y. D., 2017. Challenges and solutions for ship recycling in China. Ocean Engineering. 137, 429-439.

Du, Z. F., 2012. The Safe and Environmentally Sound Recycling of Ships and its Application in China. Advanced Materials Research. 490, 2704-2708

Du, Z. F., Wang, H., Xu, H., Li, C., Yan, H. S., Xu, H. L., ... \& Li, H. W., 2012. Discussion on Control of Hazardous Materials in Ship Recycling Activities. In: Advanced Materials Research (Vol. 476, pp. 1674-1677). Trans Tech Publications.

Elkington, J., 1998. Partnerships from cannibals with forks: The triple bottom line of 21stcentury business. Environmental Quality Management, 8(1), 37-51.

Engström, B., Henriks-Eckerman, M. L., \& Ånäs, E.,1990. Exposure to paint degradation products when welding, flame cutting, or straightening painted steel. American Industrial Hygiene Association Journal, 51(10), 561-565. 
Fereday, J., \& Muir-Cochrane, E., 2006. Demonstrating rigor using thematic analysis: A hybrid approach of inductive and deductive coding and theme development. International journal of qualitative methods, 5(1), 80-92.

Frey, R. S.,2015 . Breaking ships in the world-system: an analysis of two ship breaking capitals, Alang-Sosiya, India and Chittagong, Bangladesh. Journal of World-Systems Research, 21(1), 25.

Galley, M., 2014. Shipbreaking: hazards and liabilities. Springer.

Garmer, K., Sjöström, H., Hiremath, A. M., Tilwankar, A. K., Kinigalakis, G., \& Asolekar, S. R., 2015. Development and validation of three-step risk assessment method for ship recycling sector. Safety science. 76, 175-189.

Garud, P., 2012. Incorporation of Global Environmental Norms into Indian Legal Systems: social and economic challenges, with special reference to ship-breaking. Procedia-Social and Behavioral Sciences. 37, 150-156.

Gimenez, C., Sierra, V., \& Rodon, J. (2012). Sustainable operations: Their impact on the triple bottom line. International Journal of Production Economics, 140(1), 149-159.

Gregson, N., Crang, M., Ahamed, F., Akhter, N., \& Ferdous, R., 2010a. Following things of rubbish value: End-of-life ships, 'chock-chocky'furniture and the Bangladeshi middle class consumer. Geoforum. 41(6), 846-854.

Gregson, N., Watkins, H., \& Calestani, M., 2010b. Inextinguishable fibres: demolition and the vital materialisms of asbestos. Environment and Planning A. 42(5), 1065-1083.

Gregson, N., 2011. Performativity, corporeality and the politics of ship disposal. Journal of Cultural Economy. 4(2), 137-156.

Gregson, N., Crang, M., Ahamed, F. U., Akter, N., Ferdous, R., Foisal, S., \& Hudson, R., 2012. Territorial Agglomeration and Industrial Symbiosis: Sitakunda-Bhatiary, Bangladesh, as a Secondary Processing Complex. Economic Geography. 88(1), 37-58.

Gregson, N., Watkins, H., \& Calestani, M., 2013. Political markets: recycling, economization and marketization. Economy and Society. 42(1), 1-25. 
Gregson, N., Crang, M., Botticello, J., Calestani, M., \& Krzywoszynska, A., 2016. Doing the 'dirty work' of the green economy: Resource recovery and migrant labour in the EU. European urban and regional studies. 23(4), 541-555.

Habibullah-Al-Mamun, M., Ahmed, M. K., Raknuzzaman, M., Islam, M. S., Negishi, J., Nakamichi, S., ... \& Masunaga, S., 2016. Occurrence and distribution of perfluoroalkyl acids (PFAAs) in surface water and sediment of a tropical coastal area (Bay of Bengal coast, Bangladesh). Science of the Total Environment. 571, 1089-1104.

Hall, T. J. ,2011. The triple bottom line: what is it and how does it work?. Indiana business review, 86(1), 4 .

Hasan, A. B., Kabir, S., Reza, A. S., Zaman, M. N., Ahsan, A., \& Rashid, M., 2013. Enrichment factor and geo-accumulation index of trace metals in sediments of the ship breaking area of Sitakund Upazilla (Bhatiary-Kumira), Chittagong, Bangladesh. Journal of Geochemical Exploration. 125, 130-137.

Hasan, A. B., Kabir, S., Reza, A. S., Zaman, M. N., Ahsan, M. A., Akbor, M. A., \& Rashid, M. M., 2013. Trace metals pollution in seawater and groundwater in the ship breaking area of Sitakund Upazilla, Chittagong, Bangladesh. Marine pollution bulletin. 71(1), 317-324.

Hillier, J., 2009. Assemblages of justice: the 'ghost ships' of Graythorp. International Journal of Urban and Regional Research: 33(3), 640-661.

Hiremath, A. M., Pandey, S. K., \& Asolekar, S. R., 2016. Development of ship-specific recycling plan to improve health safety and environment in ship recycling yards. Journal of Cleaner Production. 116, 279-298.

Hiremath, A. M., Tilwankar, A. K., \& Asolekar, S. R., 2015. Significant steps in ship recycling vis-a-vis wastes generated in a cluster of yards in Alang: a case study. Journal of Cleaner Production. 87, 520-532.

Ho, S. F., Wong, P. H., \& Kwok, S. F., 1989. Study on the health hazards of scrap metal cutters. Headache. 8, 13.

Hossain, A. (2018). Determination of Reusable and Waste Material from Ship Recycling Industry of Bangladesh by Broad Sampling of Data. Available at SSRN 3252979. 
Hossain, M. S., Chowdhury, S. R., Jabbar, S. A., Saifullah, S. M., \& Rahman, M. A. ,2008. Occupational health hazards of ship scrapping workers at Chittagong coastal zone, Bangladesh. Chiang Mai J. Sci, 35(2), 370-381.

Hossain, M. S., Fakhruddin, A. N. M., Chowdhury, M. A. Z., \& Gan, S. H., 2016. Impact of ship-Breaking activities on the coastal environment of Bangladesh and a management system for its sustainability. Environmental Science \& Policy. 60, 84-94.

Humphrey, J., 1995. Industrial reorganization in developing countries: from models to trajectories. World Development, 23(1), 149-162.

Islam, K. L., \& Hossain, M. M., 1986. Effect of ship scrapping activities on the soil and sea environment in the coastal area of Chittagong, Bangladesh. Marine Pollution Bulletin. 17(10), 462-463.

Iqbal, K. M. J., \& Heidegger, P., 2013. Pakistan shipbreaking outlook: the way forward for a green ship recycling industry-environmental, health and safety conditions. Sustainable Development Policy Unit and NGO Shipbreaking Platform, Islamabad/Brussels.

Jain, K. P., \& Pruyn, J., 2018. Investigating the prospects of using a plasma gasification plant to improve the offer price of ships recycled on large-sized 'green'yards. Journal of Cleaner Production, 171, 1520-1531.

Jain, K. P., Pruyn, J. F. J., \& Hopman, J. J., 2015. Influence of ship design on ship recycling. Maritime Technology and Engineering. 269-276.

Jain, K. P., Pruyn, J. F. J., \& Hopman, J. J., 2016. Quantitative assessment of material composition of end-of-life ships using onboard documentation. Resources, Conservation and Recycling. 107, 1-9.

Jain, K. P., Pruyn, J. F. J., \& Hopman, J. J., 2017. Material flow analysis (MFA) as a tool to improve ship recycling. Ocean Engineering. 130, 674-683.

Jain, K. P., Pruyn, J. F. J., \& Hopman, J. J., 2017. Strategic guidance based on the concept of cleaner production to improve the ship recycling industry. Environment Systems and Decisions, 1-11.

Jamali, D., 2006. Insights into triple bottom line integration from a learning organization 
perspective, Business Process Management Journal, Vol. 12 Issue: 6, pp.809-821, https:// doi.org/10.1108/14637150610710945

Jamali, D., \& Keshishian, T., 2009. Uneasy alliances: Lessons learned from partnerships between businesses and NGOs in the context of CSR. Journal of business Ethics, 84(2), 277-295.

Jamali, D., \& Neville, B., 2011. Convergence versus divergence of CSR in developing countries: An embedded multi-layered institutional lens. Journal of Business Ethics, 102(4), 599-621.

Kacar, A., \& Kocyigit, A., 2013. Characterization of heavy metal and antibiotic resistant bacteria isolated from Aliaga Ship Dismantling Zone, Eastern Aegean Sea, Turkey. International Journal of Environmental Research. 7(4), 895-902.

Kagkarakis, N. D., Merikas, A. G., \& Merika, A., 2016. Modelling and forecasting the demolition market in shipping. Maritime Policy \& Management. 43(8), 1021-1035.

Kaiser, M. J., 2008. A review of ship breaking and rig scrapping in the Gulf of Mexico. Ocean Development \& International Law. 39(2), 178-199.

Kara, M., Dumanoğlu, Y., Altıok, H., Elbir, T., Odabası, M., \& Bayram, A., 2014. Spatial distribution and source identification of trace elements in topsoil from heavily industrialized region, Aliaga, Turkey. Environmental monitoring and assessment. 186(10), 6017-6038.

Kara, M., Dumanoglu, Y., Altiok, H., Elbir, T., Odabasi, M., \& Bayram, A., 2015. Spatial variation of trace elements in seawater and sediment samples in a heavily industrialized region. Environmental Earth Sciences. 73(1), 405-421.

Kara, M., Hopke, P. K., Dumanoglu, Y., Altiok, H., Elbir, T., Odabasi, M., \& Bayram, A., 2015. Characterization of PM using multiple site data in a heavily industrialized region of Turkey. Aerosol Air Qual. Res. 15, 11-27.

Karim, M. S., 2015. Prevention of Pollution of the Marine Environment from Vessels. Springer.

Karlis, T., \& Polemis, D., 2016. Ship demolition activity: A monetary flow process approach. Pomorstvo, 30(2), 128-132. 
Karlis, T., Polemis, D., \& Georgakis, A., 2016. Ship demolition activity. An evaluation of the effect of currency exchange rates on ship scrap values. SPOUDAI-Journal of Economics and Business. 66(3), 53-70.

Khan, I., Chowdhury, H., Alam, F., \& Kumar, A., 2012. Sustainable design of ship breaking industry in developing countries. Asian Journal of Water, Environment and Pollution. 9(1), 1-11.

Khan, M. A. A., \& Khan, Y. S. A., 2003. Trace metals in littoral sediments from the North east coast of the Bay of Bengal along the ship breaking area, Chittagong, Bangladesh. Journal of Biological Sciences. 3(11), 1050-1057.

Khan, M. Z. H., Hasan, M. R., Khan, M., Aktar, S., \& Fatema, K., 2017. Distribution of Heavy Metals in Surface Sediments of the Bay of Bengal Coast. Journal of toxicology. 2017.

Khandaker, N., 2017. Comment on "Ship Breaking and the Steel Industry in Bangladesh: A Materials Flow Perspective" An Argument for Saving the Baby while Throwing away the Bathwater with Caveat. Journal of Industrial Ecology. 21(1), 204-204.

Kibria, G., Hossain, M. M., Mallick, D., Lau, T. C., \& Wu, R., 2016. Monitoring of metal pollution in waterways across Bangladesh and ecological and public health implications of pollution. Chemosphere. 165, 1-9.

Knapp, S., Kumar, S. N., \& Remijn, A. B., 2008. Econometric analysis of the ship demolition market. Marine Policy. 32(6), 1023-1036.

Ko, N., Gantner, J., \& Wehner, D., 2015. Life cycle assessment of ships with special consideration of ship scrapping. Matériaux \& Techniques. 103(1), 101.

Ko, N., \& Gantner, J., 2016. Local added value and environmental impacts of ship scrapping in the context of a ship's life cycle. Ocean Engineering, 122, 317-321.

Krippendorff, K. (2018). Content analysis: An introduction to its methodology. Sage publications.

Kurt, R. E., McKenna, S. A., Gunbeyaz, S. A., \& Turan, O., 2017. Investigation of occupational noise exposure in a ship recycling yard. Ocean Engineering. 137, 440-449. 
Kusumaningdyah, W., Eunike, A., \& Yuniarti, R.,2013. Modeling tradeoff in ship breaking industry considering sustainability aspects: A system dynamics approach. Procedia Environmental Sciences. 17, 785-794.

Matz-Lück, N., 2010. Safe and Sound Scrapping of 'Rusty Buckets'? The 2009 Hong Kong Ship Recycling Convention. Review of European Community \& International Environmental Law. 19(1), 95-103.

McCallum, R. I., Sanderson, J. T., \& Richards, A. E., 1968. The lead hazard in shipbreaking: The prevalence of anaemia in burners. Annals of Occupational Hygiene. 11(2), 101-113.

Mckenney, T., 1994. Feasibility of a Ship Scrapping Yard in Philadelphia. Journal of Ship Production.

Memon, A. A., \& Zarar, M., 2016. Comprehensive Analysis of Existing Infrastructure Conditions Correlating Ship-Breaking Activities and its Implications on Workers and Community a Case Study of Gaddani Town and Ship-Breaking Industry, Baluchistan, Pakistan. American Scientific Research Journal for Engineering, Technology, and Sciences (ASRJETS). 17(1), 245-257.

Mikelis, N. E., 2008. A statistical overview of ship recycling. WMU Journal of Maritime Affairs. 7(1), 227-239.

Misra, H., 2008. Skill and education in income determination: a case study of unorganised workers of Alang. Ind J Lab Econ. 51(4), 949-955.

Misra, H., 2009. Rights of Migrant Labour at the Alang Ship Breaking Yard. Indian Journal of Social Work. 70(3), 487-498.

Moncayo, G. A., 2016. International law on ship recycling and its interface with EU law. Marine pollution bulletin. 109(1), 301-309.

Muhibbullah, M., 2013. Health hazards and risks vulnerability of ship breaking workers: A case study on Sitakunda ship breaking industrial area of Bangladesh. Global Advanced Research Journal of Geography and Regional Planning. 02 (08), 172-184.

Nandeshwar, A. R., \& Creese, R. C. , 2003. Improvement curve cost model and revenue cost model. AACE International Transactions, ES201. 
Neşer, G., Kontas, A., Ünsalan, D., Altay, O., Darılmaz, E., Uluturhan, E., ... \& Yercan, F., 2012a. Polycyclic aromatic and aliphatic hydrocarbons pollution at the coast of Aliağa (Turkey) ship recycling zone. Marine Pollution Bulletin. 64(5), 1055-1059.

Neşer, G., Kontas, A., Ünsalan, D., Uluturhan, E., Altay, O., Darılmaz, E., ... \& Yercan, F., 2012b. Heavy metals contamination levels at the Coast of Aliağa (Turkey) ship recycling zone. Marine pollution bulletin. 64(4), 882-887.

Neşer, G., Ünsalan, D., Tekoğul, N., \& Stuer-Lauridsen, F., 2008. The shipbreaking industry in Turkey: environmental, safety and health issues. Journal of cleaner production. 16(3), 350-358.Nosal, R. M., \& Wilhelm, W. J., 1989. Lead toxicity in the shipbreaking industry: the Ontario experience. Canadian journal of public health. 81(4), 259-262.

Nøst, T. H., Halse, A. K., Randall, S., Borgen, A. R., Schlabach, M., Paul, A., ... \& Breivik, K., 2015. High concentrations of organic contaminants in air from ship breaking activities in Chittagong, Bangladesh. Environmental science \& technology. 49(19), 11372-11380.

Nvivo. 2017. Accessed at http://www.qsrinternational.com/nvivo/what-is-nvivo

Odabasi, M., Ozgunerge Falay, E., Tuna, G., Altiok, H., Kara, M., Dumanoglu, Y., ... \& Elbir, T., 2015. Biomonitoring the spatial and historical variations of persistent organic pollutants (POPs) in an industrial region. Environmental science \& technology. 49(4), 2105-2114.

Odabasi, M., Tolunay, D., Kara, M., Falay, E. O., Tuna, G., Altiok, H., ... \& Elbir, T., 2016. Investigation of spatial and historical variations of air pollution around an industrial region using trace and macro elements in tree components. Science of the Total Environment, 550, 1010-1021.

Okay, O. S., Ozmen, M., Güngördü, A., Yılmaz, A., Yakan, S. D., Karacık, B., ... \& Schramm, K. W., 2016. Heavy metal pollution in sediments and mussels: assessment by using pollution indices and metallothionein levels. Environmental monitoring and assessment. 188(6), 1-18.

Ostrom, E. (2009). A general framework for analyzing sustainability of social-ecological systems. Science, 325(5939), 419-422. 
Oxman, A. D., \& Guyatt, G. H. 1993. The science of reviewing research. Annals of the New York Academy of Sciences, 703(1), 125-134.

Patel, V., Jain, S., \& Madamwar, D., 2012. Naphthalene degradation by bacterial consortium (DV-AL) developed from Alang-Sosiya ship breaking yard, Gujarat, India. Bioresource technology. 107, 122-130.

Patel, V., Munot, H., Shah, V., Shouche, Y. S., \& Madamwar, D., 2015. Taxonomic profiling of bacterial community structure from coastal sediment of Alang-Sosiya shipbreaking yard near Bhavnagar, India. Marine pollution bulletin. 101(2), 736-745.

Patel, V., Munot, H., Shouche, Y. S., \& Madamwar, D., 2014. Response of bacterial community structure to seasonal fluctuation and anthropogenic pollution on coastal water of Alang-Sosiya ship breaking yard, Bhavnagar, India. Bioresource technology. 161, 362370.

Patel, V., Patel, J., \& Madamwar, D., 2013. Biodegradation of phenanthrene in bioaugmented microcosm by consortium ASP developed from coastal sediment of AlangSosiya ship breaking yard. Marine pollution bulletin. 74(1), 199-207.

Puthucherril, T. G.,2010. From shipbreaking to sustainable ship recycling: Evolution of a legal regime. Brill.

Radonja, R., \& Jugović, A. 2011. Shipowners' Business Policy in the Context of Development in the Environmental Legislation. Scientific Journal of Maritime Research. 25(2).

Rahman, S. M., \& Mayer, A. L., 2016. Policy compliance recommendations for international shipbreaking treaties for Bangladesh. Marine Policy. 73, 122-129.

Rahman, S. M., Handler, R. M., \& Mayer, A. L., 2016. Life cycle assessment of steel in the ship recycling industry in Bangladesh. Journal of Cleaner Production. 135, 963-971.

Rahman, S. M., \& Mayer, A. L., 2015. How social ties influence metal resource flows in the Bangladesh ship recycling industry. Resources, Conservation and Recycling. 104, 254-264.

Rahman, S.M. \& Kim, J., 2019 (under review), Circular Economy, Proximity, and Shipbreaking: A Material Flow and Environmental Impact Analysis. Environmental Science \& Technology. 
Rahman, S.M.M., Schelly, C.; Mayer, A.L.; Norman, E.S., 2018. Uncovering Discursive Framings of the Bangladesh Shipbreaking Industry. Soc. Sci. 7, 14.

Reddy, M. S., Basha, S., Adimurthy, S., \& Ramachandraiah, G., 2006. Description of the small plastics fragments in marine sediments along the Alang-Sosiya ship-breaking yard, India. Estuarine, Coastal and Shelf Science. 68(3), 656-660.

Reddy, M. S., Basha, S., Joshi, H. V., \& Ramachandraiah, G., 2005. Seasonal distribution and contamination levels of total PHCs, PAHs and heavy metals in coastal waters of the Alang-Sosiya ship scrapping yard, Gulf of Cambay, India. Chemosphere. 61(11), 15871593.

Reddy, M. S., Basha, S., Kumar, V. S., Joshi, H. V., \& Ghosh, P. K.,2003 . Quantification and classification of ship scraping waste at Alang-Sosiya, India. Marine pollution bulletin. 46(12), 1609-1614.

Reddy, M. S., Basha, S., Kumar, V. S., Joshi, H. V., \& Ramachandraiah, G., 2004. Distribution, enrichment and accumulation of heavy metals in coastal sediments of Alang-Sosiya ship scrapping yard, India. Marine Pollution Bulletin. 48(11), 1055-1059.

Reddy, M. S., Basha, S., Joshi, H. V., Kumar, V. S., Jha, B., \& Ghosh, P. K., 2005. Modeling the energy content of combustible ship-scrapping waste at Alang-Sosiya, India, using multiple regression analysis. Waste Management, 25(7), 747-754.

Reddy, N. G. K., 2014. Ship Recycling: An Important Mile Stone for India. Indian Journal of Science and Technology. 7, 15.

Robins, F., 2006. The challenge of TBL: a responsibility to whom?. Business and Society Review, 111(1), 1-14.

Rousmaniere, P., \& Raj, N., 2007. Shipbreaking in the developing world: problems and prospects. International journal of occupational and environmental health. 13(4), 359-368.

Sahu, G., 2014. Workers of Alang-Sosiya. Economic \& Political Weekly. 49(50), 53.

Sarraf, M., Stuer-Lauridsen, F., Dyoulgerov, M., Bloch, R., Wingfield, S., \& Watkinson, R., 2010. Ship breaking and recycling industry in Bangladesh and Pakistan. The World Bank, Washington. 
Schøyen, H., Burki, U., \& Kurian, S., 2017. Ship-owners' stance to environmental and safety conditions in ship recycling. A case study among Norwegian shipping managers. Case Studies on Transport Policy. https://doi.org/10.1016/j.cstp.2017.06.003.

Seuring, S., \& Müller, M., 2008. From a literature review to a conceptual framework for sustainable supply chain management. Journal of cleaner production. 16(15), 1699-1710.

Shah, B., Jain, K., Patel, N., Pandit, R., Patel, A., Joshi, C. G., \& Madamwar, D., 2015. Draft genome sequence of Paenibacillus sp. strain DMB20, isolated from Alang shipbreaking yard, which harbors genes for xenobiotic degradation. Genome announcements. 3(3), e00554-15.

Sharifuzzaman, S. M., Rahman, H., Ashekuzzaman, S. M., Islam, M. M., Chowdhury, S. R., \& Hossain, M. S. (2016). Heavy metals accumulation in coastal sediments. In: Environmental Remediation Technologies for Metal-Contaminated Soils (pp. 21-42). Springer, Japan.

Siddiquee, N. A., Parween, S., Quddus, M. M. A., \& Barua, P., 2009. Heavy metal pollution in sediments at ship breaking area of Bangladesh. Asian Journal of Water, Environment and Pollution. 6(3), 7-12.

Sivaprasad, K., \& Nandakumar, C. G., 2013. Design for ship recycling. Ships and Offshore Structures. 8(2), 214-223.

Sonak, S., Sonak, M., \& Giriyan, A., 2008. Shipping hazardous waste: implications for economically developing countries. International Environmental Agreements: Politics, Law and Economics. 8(2), 143-159.

Sujauddin, M., Koide, R., Komatsu, T., Hossain, M. M., Tokoro, C., \& Murakami, S., 2015. Characterization of ship breaking industry in Bangladesh. Journal of Material Cycles and Waste Management. 17(1), 72-83.

Sujauddin, M., Koide, R., Komatsu, T., Hossain, M. M., Tokoro, C., \& Murakami, S., 2017. Ship Breaking and the Steel Industry in Bangladesh: A Material Flow Perspective. Journal of Industrial Ecology. 21(1), 191-203.

Sunaryo, S., \& Pahalatua, D., 2015. Green ship recycle yard design. Journal of Naval Architecture and Marine Engineering. 12(1), 15-20. 
Tewari, A., Joshi, H. V., Trivedi, R. H., Sravankumar, V. G., Raghunathan, C., Khambhaty, Y., ... \& Mandal, S. K.,2001. The effect of ship scrapping industry and its associated wastes on the biomass production and biodiversity of biota in in situ condition at Alang. Marine Pollution Bulletin, 42(6), 461-468.

Tiwari, R. R., Dave, S. K., Tripathi, S. R., Sathwara, N. G., Majumdar, P. K., Patel, B. D., ... \& Vyas, J. B., 2008. Health Hazards in Ship Breaking Workers of Alang.

Tola, S., \& Karskela, V.,1976. Occupational lead exposure in Finland: V. Shipyards and shipbreaking. Scandinavian journal of work, environment \& health, 31-36.

Touboulic, A. , 2017. Are We really doing the "right thing"? From sustainability imperialism in global supply chains to an inclusive emerging economy perspective. In Implementing Triple Bottom Line Sustainability into Global Supply Chains (pp. 2241). Routledge.

Webster, J., \& Watson, R. T., 2002. Analyzing the past to prepare for the future: Writing a literature review. MIS quarterly, xiii-xxiii.

Welaya, Y. M., Naby, M. M. A., \& Tadros, M. Y., 2012. Technological and economic study of ship recycling in Egypt. International Journal of Naval Architecture and Ocean Engineering. 4(4), 362-373.

Widmer, R., Oswald-Krapf, H., Sinha-Khetriwal, D., Schnellmann, M., \& Böni, H., 2005. Global perspectives on e-waste. Environmental impact assessment review, 25(5), 436458.

Wu, W. T., Lin, Y. J., Li, C. Y., Tsai, P. J., Yang, C. Y., Liou, S. H., \& Wu, T. N., 2015. Cancer attributable to asbestos exposure in shipbreaking workers: a matched-cohort study. PloS one, 10(7), e0133128.

Wu, W. T., Lu, Y. H., Lin, Y. J., Yang, Y. H., Shiue, H. S., Hsu, J. H., ... \& Wu, T. N., 2013. Mortality among shipbreaking workers in Taiwan-a retrospective cohort study from 1985 to 2008. American journal of industrial medicine, 56(6), 701-708.

Yin, J., \& Fan, L., 2018. Survival analysis of the world ship demolition market. Transport Policy, 63, 141-156. 
Yozukmaz, A., Sunlu, F. S., Sunlu, U., \& Ozsuer, M., 2011. The determination of organotin compounds levels in sediment samples from Turkish Aegean Sea coast. Turkish Journal of Fisheries and Aquatic Sciences, 11(4).

Yujuico, E., 2014. Demandeur pays: The EU and funding improvements in South Asian ship recycling practices. Transportation Research Part A: Policy and Practice. 67, 340351.

ZafarUllah, W. W., Guo, P., \& Xiaoru, X., 2016. The Coastal Zone Issues of Pakistan and Counter Measure Managements through an Integration Approach. U.J. Sci Tech. lasbela. Zott, C., Amit, R., \& Massa, L., 2011. The business model: recent developments and future research. Journal of management, 37(4), 1019-1042.

Zhang, H., 2016. Pollution from EOLV dismantling and the corresponding countermeasures. Marine pollution bulletin, 106(1-2), 25-30.

Zhao, Y., \& Chang, Y. C., 2014. A Comparison of Ship-Recycling Legislation Between Chinese Law and the 2009 Hong Kong Convention. Ocean Development \& International Law. 45(1), 53-66. 